\title{
Touching the Hem: \\ The Thread between Garment and Blood in \\ the Story of the Woman with the Haemorrhage (Mark 5:24b-34parr)

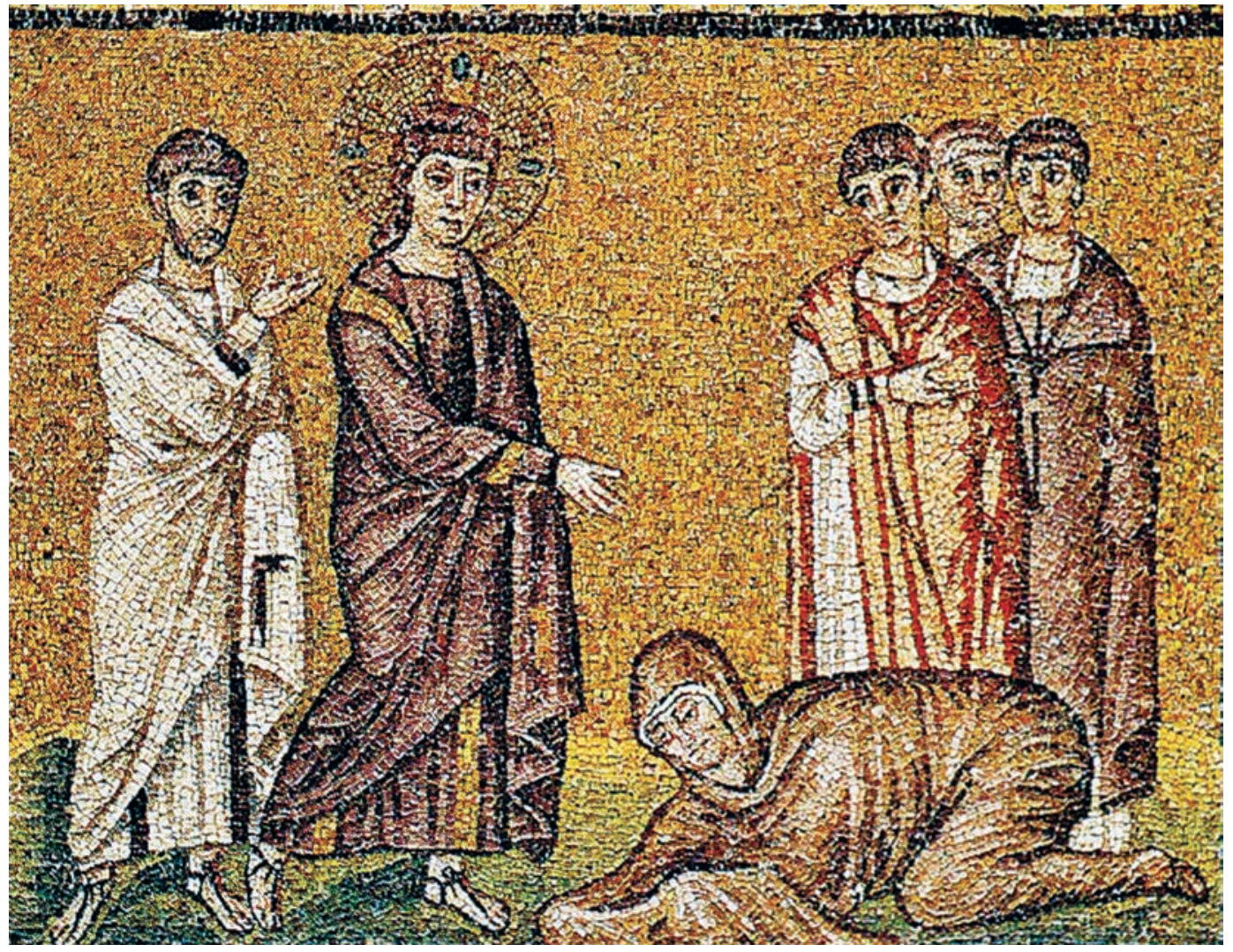




\section{Abstract}

$\mathrm{n}$ this article I start from a

particular passage in the New

Testament that will touch on biblical thos threads and paradigms related to textile. Mark 5:24b-34, Luke 8:42-48, and Matthew 9:19-22 tell the story of the healing of the "woman with an issue of blood," the Haemorrhoissa. This story (and its Nachleben in commentaries and iconographies) pulsates with a delicate energy relating to textile,

Keywords: Haemorrhaging Woman, Christianity, textile, cloth, hem, visuality, vera icon cloth, and the magical impact of touch. I will firstly investigate upon those textile-related dimensions by situating the passage in what I term its narrative, iconic, and anthropological space. This will finally lead to a hypothesis on the origin of the medieval assimilation of the Haemorrhoissa to the Veronica, the woman who carried the imprint of Christ's face.

\section{SIDGWICK)}

Barbara Baert is professor of art and art history at K. U. Leuven. In 2008 she founded the Iconology Research Group, an international and interdisciplinary platform for the study of the interpretation of images. Her recent books (edited) are Weaving, Veiling, and Dressing: Textiles and Their Metaphors in the Late Middle Ages (Brepols 2007) and Fluid Flesh: The Body, Religion and the Visual Arts (Lieven Gevaert Studies in Photography and Visual studies 2009).

Textile, Volume 9, Issue 3, pp. 308-351 DOI: XXXX

Reprints available directly from the Publishers.

Photocopying permitted by licence only.

(c) 2011 Berg. Printed in the United Kingdom. 


\section{Touching the Hem: The Thread between Garment and Blood in the Story of the Woman with the Haemorrhage (Mark 5:24b-34parr)}

\author{
Il n'y a pas d'abord la \\ signification, la traduction, \\ l'interprétation: \\ il y a cette limite, ce bord, ce \\ contour, cette extrémité, ce \\ plan "d'esposition", \\ cette couleur-sujet locale, \\ qui peut simultanément se \\ contracter.(...) \\ Cela seulement peut fermer \\ ou dégager de l'espace \\ pour des "interprétations." \\ (Nancy 2000: 23)
}

At the outset, there is no signification, translation, or interpretation:

there is this limit, this edge, this contour, this extremity, this outline,

this local subject-color, which can be withdrawn, concentrated, (...).

This alone can close or release a space for "interpretations." (Nancy 2008: 23)

One of God's first acts of provision for humankind after the fall is to make "garments of skins for the man and for his wife and clothe them" (Gen. 3:21) (Rubin and Kosman 1997). The world of the Bible, especially for what concerns its Christian understanding, is covered with garments, wool, cloths, textiles, threads, and veils. Not speaking and writing, but knotting and weaving seem to be the appropriate ways to understand Christian anthropology. The seedbed of this Christian anthropology can indeed be found in the Old Testament; already their clothing is rarely neutral (Ryken 1998: 318-9). As we understand from the prophets, it is the image for those who live in the presence of the Lord (Ezekiel 16:13 and Isaiah 23:18). Nature is part of the clothing of God, wrapped in light as a garment, sings Psalm 104:2. There were garments unique to prophets, such as Elijah's mantle (1 Kings 19:13). Putting on and taking off clothes signifies the transformation from one role or state of mind to the other, such as priesthood, mourning or becoming a bride. Garments help to link the natural and supernatural world. The weaving of the thread in the womb of Psalm 139:15 ("You knit me together in my mother's womb"), and Moses veiling his face after having seen God in Exodus $34: 28-35$, preserved the very seed for the fundamental paradigms of incarnation and visible invisibility. In fact, garments and by extension 
textiles are mysterious and multisensory threads connecting the glory of God to mankind that is at His service.

In this article I start from a particular passage in the New Testament that will touch these multi-sensory threads and paradigms. Mark 5:24b-34, Luke 8:42-48, and Matthew 9:19-22 tell the story of the healing of the "woman with an issue of blood," the Haemorrhoissa. ${ }^{1}$ This story (and its Nachleben in commentaries and iconographies) pulsates with a delicate energy relating to textile, cloth and the magical impact of touch.

And a large crowd followed him and pressed in on him. ${ }^{25}$ Now there was a woman who had been suffering from hemorrhages for twelve years. ${ }^{26}$ She had endured much under many physicians, and had spent all that she had; and she was no better, but rather grew worse. ${ }^{27}$ She had heard about Jesus, and came up behind him in the crowd and touched his cloak, ${ }^{28}$ for she said "If I but touch his clothes, I will be made well." $29 /$ mmediately her haemorrhage stopped; and she felt in her body that she was healed of her disease.

$30 /$ mmediately aware that power had gone forth from him, Jesus turned about in the crowd and said, 'Who touched my clothes?' ${ }^{11}$ And his disciples said to him, "You see the crowd pressing in on you; how can you say, 'Who touched me?"' ${ }^{32} \mathrm{He}$ looked all round to see who had done it. ${ }^{33}$ But the woman, knowing what had happened to her, came in fear and trembling, fell down before him, and told him the whole truth. ${ }^{34 \mathrm{He} \text { said }}$ to her, "Daughter, your faith has made you well; go in peace, and be healed of your disease." (Mark 5:24b-34)

\section{The Narrative Space: Touch and Textile}

The Haemorrhoissa is the interruption of Jesus' requested cure of the daughter of Jairus. The bleeding woman appears suddenly out of the crowd with a strong desire to be cured of her hemorrhage-siccatus est fons sanguinis eius. The reference to the fons in verse 29 , refers to the fact that her hemorrhage was a uterine problem, and not for example a nosebleed. Another argument in the secondary exegetical literature, is that the fact that the flow not being located exactly-mulier quae erat in profluvio sanguinis annis duodecim (Mk 5:25)-might indicate discretion, even shame in Mark's redaction. Marla Selvidge and Judith Plaskow discern antiJudaic sympathies in Mark, in view of a deliberate healing of a woman that would be an outcast in Jewish society, ${ }^{3}$ given the purity regulations in Leviticus (12:7, 15:19-33, 20:18), Numbers and Deuteronomy (Selvidge 1990; Plaskow 1993). 4 The woman with the hemorrhage might have been a so-called zabâ, a woman suffering from irregular menstrual bleeding, one who, according to Leviticus, could not be touched. 5 In short, the passage in Mark becomes contextualized in paleo-Christian culture, in menstruations and blood-flow taboos with a central focus on tactility.
Christ's miracles of healing are carried out through the word, through touch, through word and touch, with the use of saliva, at a distance, or through incision (Wilkinson 1998; van der Loos 1965: 510). The Haemorrhoissa clearly belongs to the category of touch: haptein, tenere. ${ }^{6}$ But the touch of the woman with the hemorrhage is peculiar for three reasons. To begin with, she initiates the touch, and the touch seems to have a strong effect on Jesus. Her fountain of blood dries out, at the exact moment that something "flows away" from Jesus. "This was no accidental brush with a stranger; it was a risky endeavour to make physical contact with the person of Jesus, if even his garment" (Bromley 2005).

Reimund Bieringer (2005) has studied the syntactic meaning and frequency of the word "touch" in the Old and New Testament. The Greek verb haptein is the most general verb for touching, but also means "to approach," "to be in contact with something or someone" or "to touch emotionally" (both in a friendly and in a harmful sense). Comparative research of the frequency and the contextual meaning of the verb haptein has shown a cultic meaning (Ex 29:37) or a taboo of touch (Leviticus and Numbers) between people, things and dead bodies. The same word is actually used in the Noli me tangere phrase: me mou haptou (John 20:17). 7 In his article Healing by a Mere Touch, Lalleman states that healing by touch is less typical of Hellenistic cults than of Judaeo-Christian healing practices (1997). ${ }^{8}$ Greek and Roman healing practice 
appealed to therapy, such as the bath therapies and dreams of the Asklepios cults (Cotter 1999: 246). ${ }^{9}$ Mark and Luke specify, moreover, that therapists had been unable to help the woman. Christ's healing, by contrast, takes place in a flash, a momentum, with no means employed, no process or therapy, and thus uniquely connects the touch-haptomaiwith the possibility of healing in a miraculous way. ${ }^{10}$

Secondly, the touch causes a fascinating breach between fluidity and petrifaction, between movement and fossilization, between process and interruption. The text even speaks of a power (dynamij; virtus) over which Christ has no control. One might sense an archaic magical effect suggested here (Bromley 2005; Clark Kee 1983: 162-3, 1984: 2-4; Cotter 1999: 246; Hull 1974: 136). According to Hippocrates (460-377 BC) dynamij means the capacity of affects: a mana-like fluid. It is an energy that is transmitted from the supra-mundane to the mundane level. Normally dynamij is not used in the Christian miracle episodes. It refers to a Hellenistic cosmic view of healing. ${ }^{11}$ But if the synoptics allude to old magical suggestions, then it is to thematize their very denial by Christ (Marshall 1989: 106-8; May 1952: 98). At the end of the episode the healing is attributed to Christ's person. He explains the miracle by referring to the woman's faith: "your faith has made you well."

Finally, we need to mention that this touch is a touch upon textile. It is, in other words, no skin-toskin contact such has the typical laying on of hands (sunanaxroosis)
(Waagenvoort 1957). The idea that power can be stored or tapped from a holy person is very old (Marcus 2000: 359). In 2 Kings 13:20-21 a strong example of this is preserved: a corpse that touches the bones in Elishas's tomb revives. Also textile has the explicit capacity to transfer essences of the owner's body. The clothing of a body constitutes that body. This is also clear in Jesus asking, "Who touched my clothes?" and the disciples' reaction: "Why would you ask 'Who touched me?"' In Acts 19:12, handkerchiefs that have touched Paul's body have the power to heal the people of Ephesus. In the Acts of John, many brothers were healed in Ephesus by touching the garments of John; the word used here is, indeed, haptomai. ${ }^{12}$

Again, according to Leviticus $15: 11,21-22$, one needs to wash not only the hands but also the clothes of one who has been touched by the afflicted. Touching a menstruant, in particular, can cancel miraculous power ("a power had gone from me"). In the Jewish Hekhalot Rabbati of the third-fourth century, a Rabbi lost his power by touching a thread that had been touched by a menstruant (Marcus 2000: 358). There are also Greco-Roman examples, such as Epidaurus 7, which states that a disease can not only be transmitted to a cloth, but be transferred in full from the sufferer to the cloth (Theissen 1983: 134). Some authors take the view that the hemorrhaging woman wished to get rid of her decease by passing it on to the garments of Christ (Theissen 1983: 134). Whether this is the case or not, the episode of the Haemorrhoissa shows some 
sort of comparable superstition at work, with the idea that touch can draw out a power. Mark's agenda was probably to show that faith can overcome superstitious fear (D’Angelo 1999: 99).

It is important to understand that for all these reasons the touch by the woman with the hemorrhage is different from other biblical healing stories. In the next section, I will investigate these characteristics in early medieval visual culture. In other words, we will make the transposition from the narrative space to the iconic space.

\section{The Iconic Space: "Textilization"}

Asterius, Bishop of Pontus in Asia

Minor, wrote $c .400$ :

The more religious among rich men and women, having picked out the story of the Gospels, have handed it over to the weavers-I mean our Christ together with all His disciples, and each one of the miracles the way it is related. You may see the wedding of Galilee with the water jars, the paralytic carrying his bed on his shoulder, the blind man healed by means of clay, the woman with an issue of blood seizing Christ's hem, the sinful woman falling at the feet of Jesus, Lazarus coming back to life from his tomb. In doing this, they consider themselves to be religious and to be wearing clothes that are agreeable to God. (Asterius of Amasia 1972: 51)

The iconography of the Haemorrhoissa was a frequent theme in paleo-Christian visual culture appearing on sarcophagi, in catacombs, and on small objects such as textiles, ivories and gems. Already in the catacomb of Peter and Marcellinus alone, five different identifications of the Haemorrhoissa are accepted in the secondary literature (see Deckers et al. 1987; Mancinelli 1987: 39-43). The fact that the theme is so popular in this catacomb makes some scholars presume that all women were buried here (Mancinelli 1987). It is moreover the catacomb also known as "ad S. Helenam," referring to the mausoleum (on the same site) of the first Christian empress, the mother of Constantine the Great.

In his essay À distance Carlo Ginzberg connects the idea of the Punctum or l'instant decisive with the very birth of Christian art. ${ }^{13}$ The Zwischenraum between the biblical text and the emergence of an iconography is characterized by vibrant moments that have the capacity to open the narrative space to the iconic. The text breaks open towards the epiphany of the visual. We can discern three such pulsating moments in the mother-text (see Baert 2009a).

The first group refers to the crawling woman, the outcast, who desires to touch (Figure 1). Tactile contact is either taking place or about to take place. The gazes between the woman and Christ do not, however, meet, as Christ is still searching elsewhere. Nor do their bodies connect. The distortion-she in profile, he frontal or turning around-embodies the transgressions that are taking place. The second group is the woman falling down, trembling, and explaining her actions in anxiety (Figure 2). Christ is looking down at her. She has lost her grasp, and fears punishment: venit et procidit (v. 33). The third group refers to the harmony and final stage of the story (Figure 3). The woman is healed, blessed, and become "whole." The woman is semi-upraised, accepting the blessing and final Christological healing moment: fides tua te salvam fecit (v. 35). The transgressing energies give way to stillness and union. There is no longer any tactile contact with Christ. The wholeness is also expressed in the mutual gazes passing between Christ and the woman. The final connection is made.

But in none of these cases is the pathology of the woman with the hemorrhage recognizable. In the images of the healing of the blind man at Siloam (In 9:1-4) (Baert 2007) the eyes are pointed to, and in those of the paralytic at the Piscina Probatica (In 5:1-8) the bed or the crutch refer to the specific handicap (Baert 2005). But in the case of the Haemorrhoissa nothing allows us to induce that the miracle might involve a hemorrhage of the uterus. It is undepictable. This can sometimes make her difficult to identify; she is often confused with Mary Magdalene, the woman of Canaan (Mt 15:22) and the humpbacked woman (Lk 13:10-17). ${ }^{14}$ In the miniature of the Codex Egberti, the miniaturist added above the woman: fluxus habens (Figure 4). ${ }^{15}$

In the Gospels, the illness of the woman is compared to a fons sanguinis. When one considers the passus as an image of the well, it suddenly becomes apparent how 
Figure 1

Christ and the Haemorrhoissa, detail of the Brescia Casket, ivory relief, c. 360-70. Brescia, Museo Civico.

Figure 2

Christ and the Haemorrhoissa, mosaic, 520-26. Ravenna, S. Apollinare Nuovo.
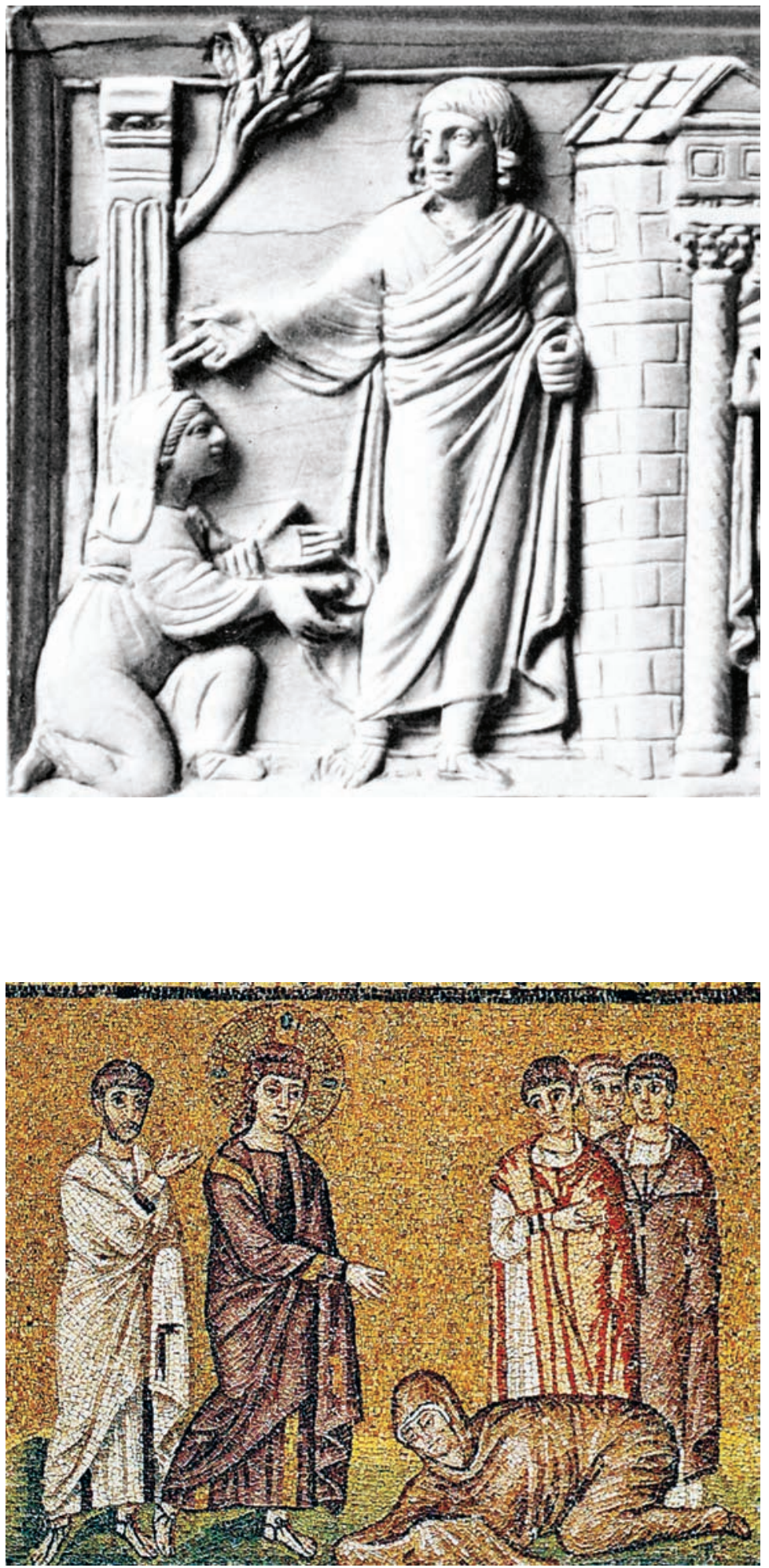
Figure 3

Christ and the Haemorrhoissa, mural in the catacomb of SS Peter and Marcellinus, third century. Rome.
Figure 4

Healing of Haemorrhoissa, miniature from the Codex Egberti, Reichenau, 977-93. Trier, Stadtbibliothek, ms. 24, fol. $90 \mathrm{v}$.
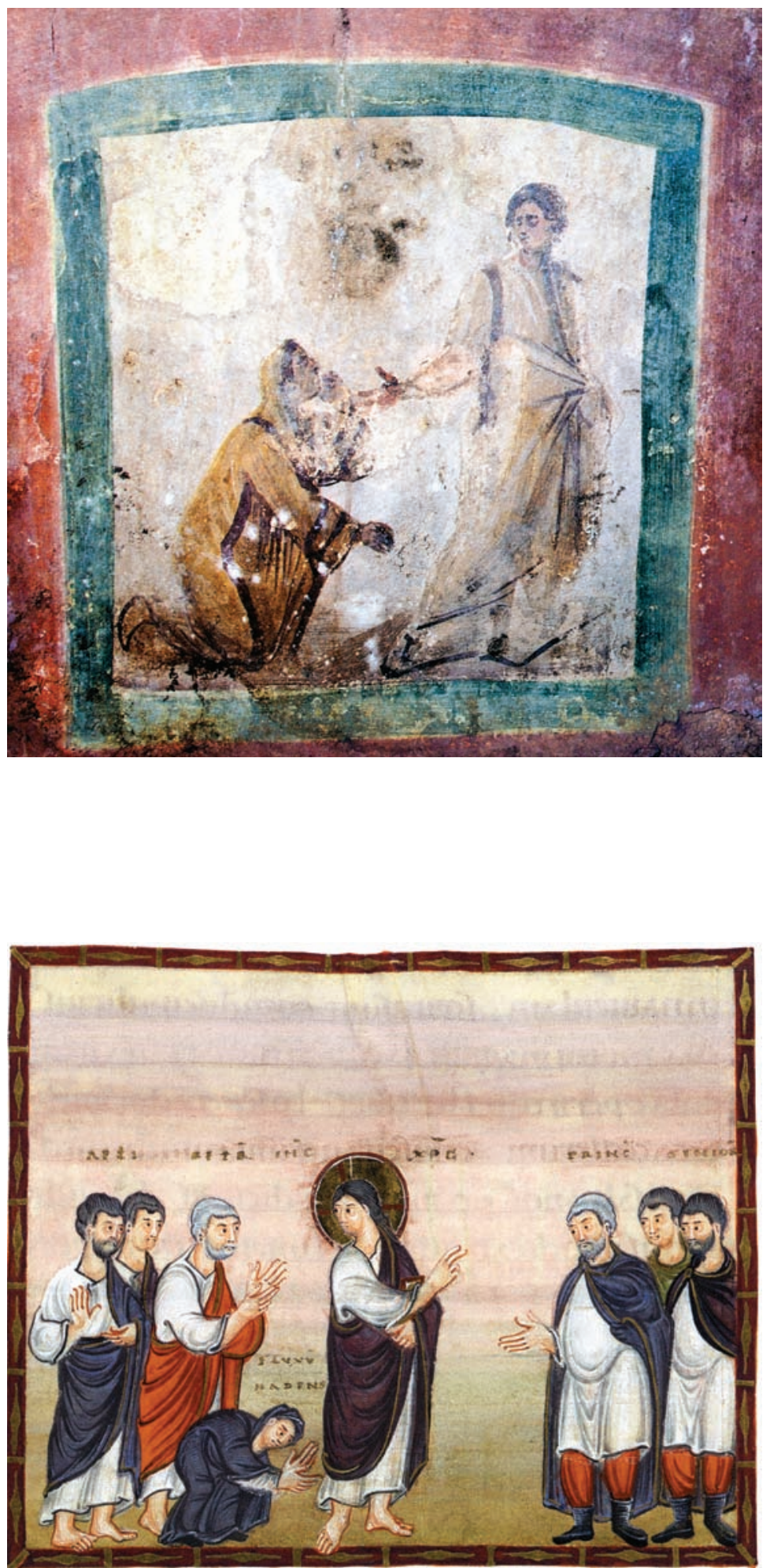
the hemorrhage is typologically combined with other biblical episodes and miracles related to fountains and/or fluidity. In the catacomb of Peter and Marcellinus, one of the Haemorrhoissas is placed to the right of Moses striking water from the rock, and the paralytic at the Piscina Probatica in Jerusalem (Figure 5; Baert 2002, 2005, 2007). The sixthcentury encolpion from Adana also places the woman alongside the healing at the Piscina Probatica (Figure 6; Schiller 1971) as does a Carolingian ivory (Figure 7). ${ }^{16}$ Another Haemorrhoissa in the catacomb of Peter and Marcellinus is combined with the Samaritan woman at the well (Figure 8). In the mosaic of Ravenna, the healing of the Haemorrhoissa precedes the Samaritan (Figure 9). On the sarcophagus in Santa Maria presso San Celso in Milan, the healing is combined with the apocryphal story of Saint Peter turning the prisoner's wall into a fountain (Figure 10; Knipp 1998: 124-5).

In other words, the iconography of the woman with the hemorrhage ties in with three fundamental categories in visual anthropology: the body, fluidity, and cloth. The role of textile in the Haemorrhoissa Nachleben is complex and multilayered. I therefore dare to speak of a "textilization" of the iconography of the Haemorrhoissa at four levels.

1. Textile and garment as the story-immanent motif.

2. Textile and cloth as pictorial metaphors and embodiment.

3. The role of textile in the material culture of the Haemorrhoissa.
4. The textile motif and the Haemorrhoissa in the debate on cult images.

\section{Textile and Garment as the Story-Immanent Motif}

Crucial in the text is of course the touching of the garment of Christ. On the Brescia Casket we see how the Haemorrhoissa is represented clearly taking the garment in her hands (Figure 1; Watson 1981). On the so-called "Tree Sarcophagus" of Arles (c. 360) we see the Haemorrhoissa huddled down, supporting herself on one knee at Christ's feet, with both hands grasping part of the hem (Figure 11). ${ }^{17}$ The same is true for the Sarcophagus of Adelphia (c. 340) in Syracuse, Sicily (Figure 12), and the sarcophagus in the Leiden museum of antiquities (Figure 13). ${ }^{18}$ In a Greek bible at the Walters Art Gallery it is, again, specifically the hem that the woman touches (Figure 14). ${ }^{19}$

The Gospels according to Luke (8:44) and Matthew (9:21) both, indeed, specify that the woman desired not simply to touch the garment of Christ, but more in particular the hem of the garment of Christ: kraspedon or fimbria (Fitzmyer 1985: 742-7). Touching the hem is a gesture one would expect from a hidden attempt to contact somebody. It implies a crawling, humble position. The hem psychologizes the Haemorrhoissa's touch as a clandestine act on the one hand, and as an act of submission on the other. Touching someone's hem is often a form of pleading with them. 
Figure 5

Wall paintings with Haemorrhoissa in the catacomb of SS Peter and Marcellinus, third century. Rome.

\section{Figure 6}

Enkolpion of Adalana, sixth century. Assiût, treasury.
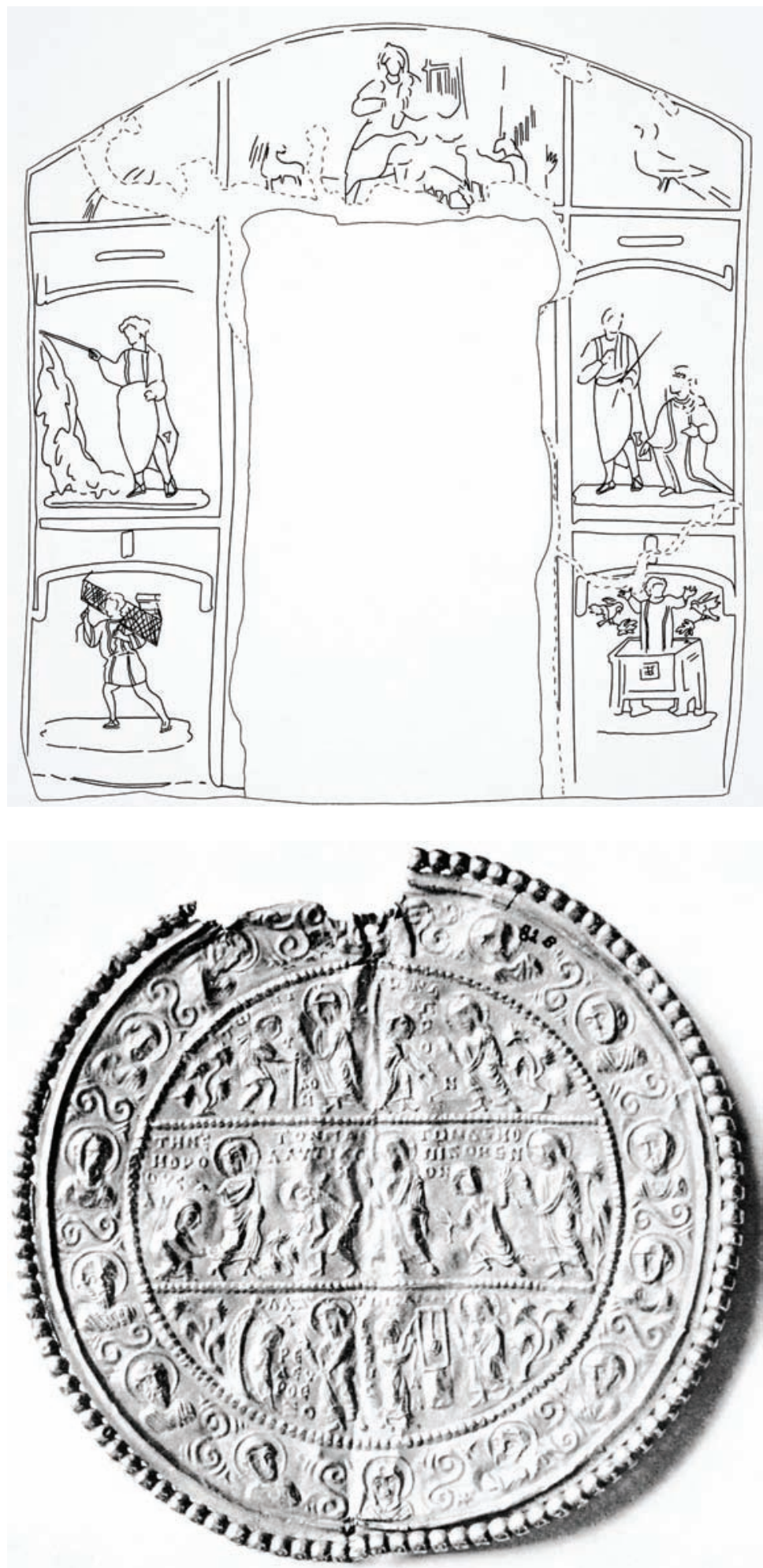
Figure 7

Healings and miracles of Christ, Court School of Charlemagne, ivory book cover, $211 \times 124 \mathrm{~cm}$, beginning of the ninth century. Oxford, Bodleian Library, Cod. Douce 176.
Besides the psychological impact, the hem has specific exegetical, material, and cultic meanings. Exegetes agree that the detail in Luke and Matthew is quoted from Mark 6:56, which says that wherever Christ went, people tried to touch the hem of his garment, and who did this, was healed (Cummings 1980: 51-2). The same idea appears later in Matthew 14:36 again: "And they besought him that they might touch but the hem of his garment. And as many

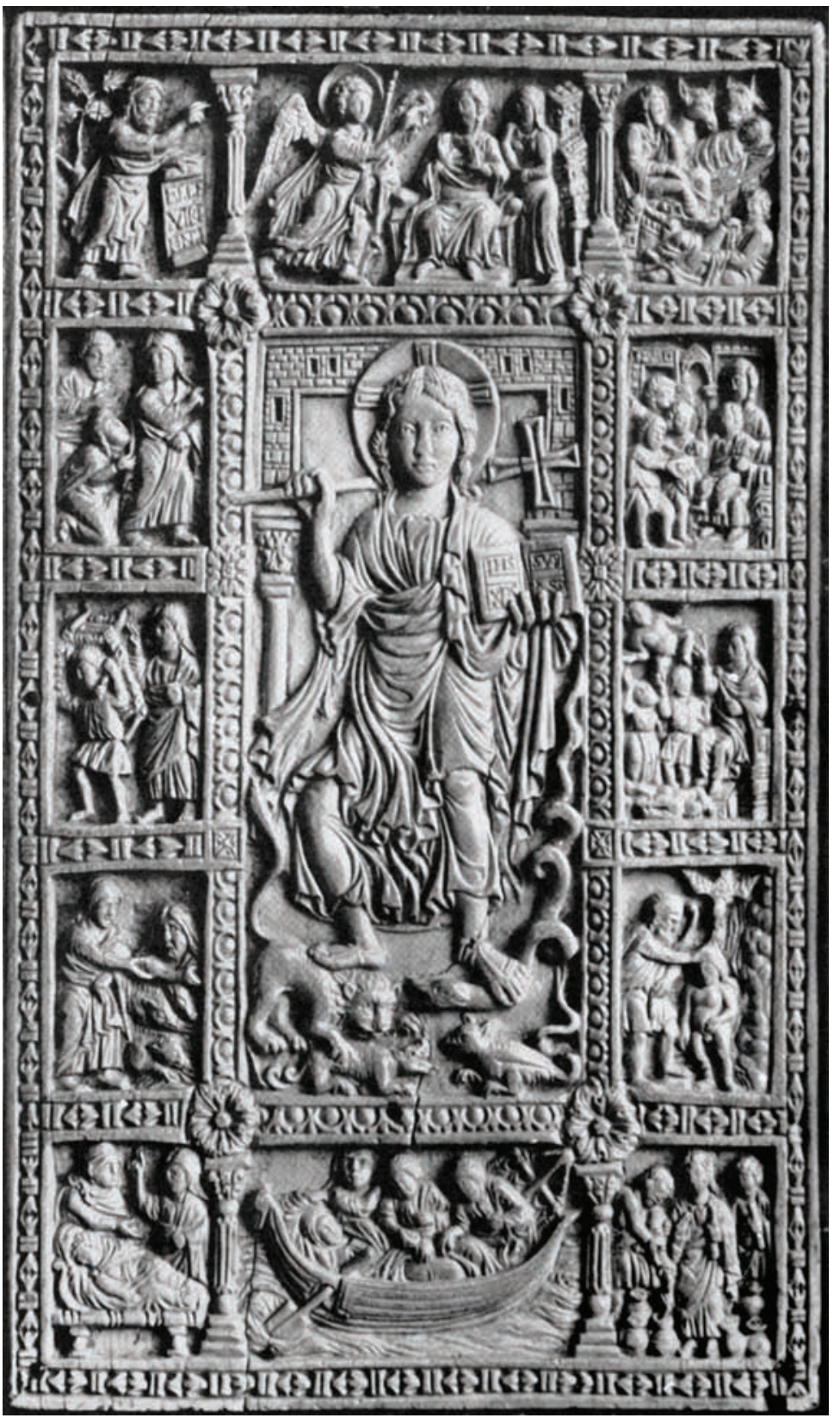


Figure 8

Wall paintings with Haemorrhoissa in the catacomb of SS Peter and Marcellinus, third century. Rome.
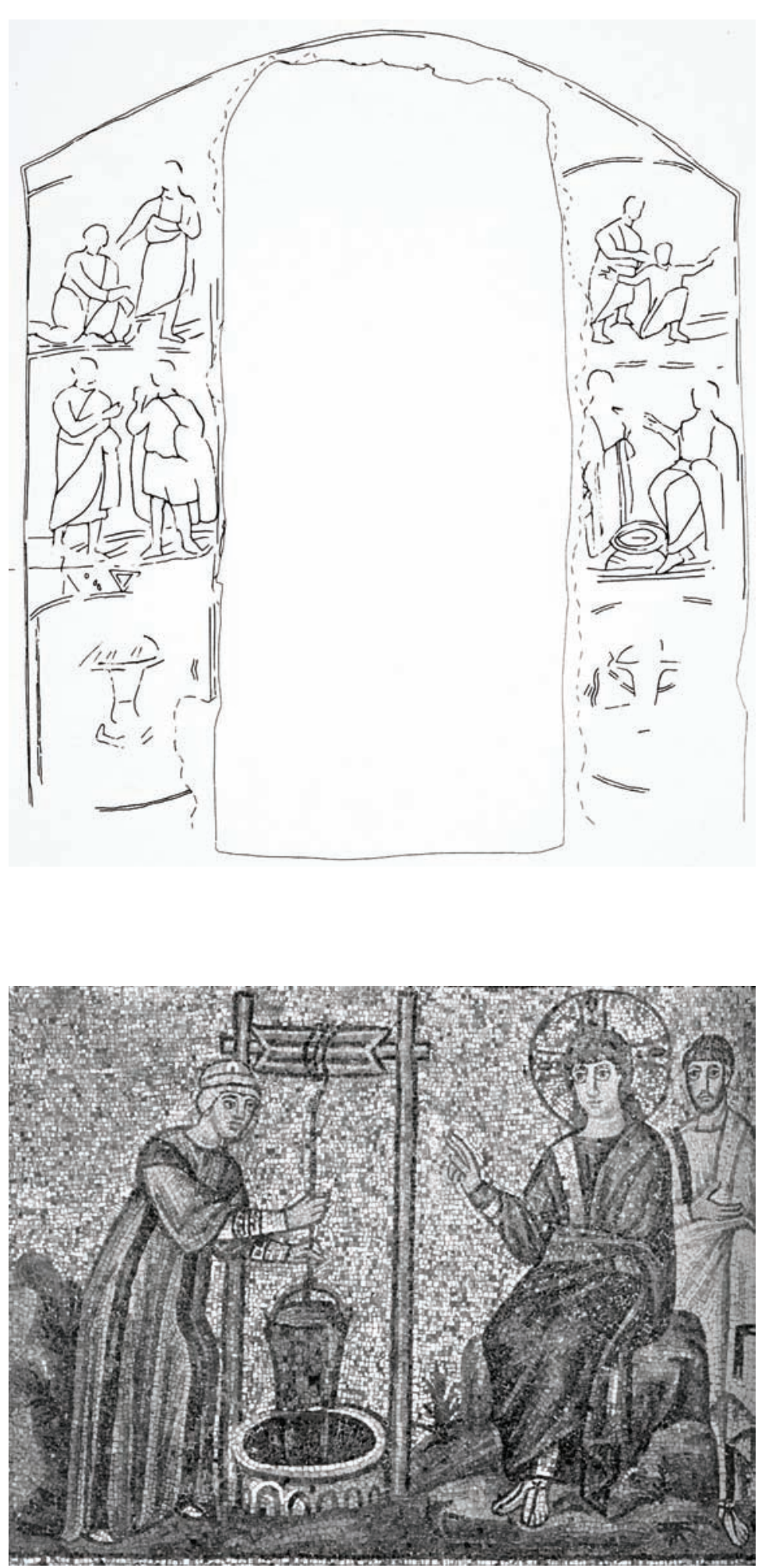

Figure 9

Christ and the Samaritan woman, mosaic, 520-6. Ravenna, S. Apollinare Nuovo. 
as touched, were made whole." Patristic sources, moreover, saw a type of the healing hem of Christ in Zechariah 8:23: "In those days ten men of all languages and nations will take firm hold of one Jew by the hem of his robe, and say: Let us go with you, because we have heard that God is with you." The prophecy referred to the exaltation of Jerusalem, to the gentiles united in an eschatological pilgrimage. In the first Christian centuries, Zechariah 8:23 was already recognized as a messianic prophecy. Jerome (347-419) for example, interpreted the hem as the Church of the apostles (Jerome 1970: 822-4). "The miracle is understood as a symbolic action that is prophetic of the coming of the kingdom and the Parousia. The woman with the hemorrhage underwent her eschatological pilgrimage to God" (Cummings 1980: 53). The fact that the hemorrhage miracle is a sea crossing miracle (Struthers Malbon 1984: 363-77), was recognized as a "new exodus" and a "new Moses" theme. The story mirrors deliverance through water to newness of life, thereby suggesting a "baptismal as well as a Eucharistic, namely paschal, context" (Cummings 1980: 53). ${ }^{20}$

This would explain the popularity of the healing in paleoChristian culture, a culture that was particularly sensitive to the approaching Heavenly Jerusalem. We can now understand that the eschatological concept of the hem as the very portal towards the new eternal life by way of water (baptism), and by way of communion (the blood of the Eucharist) led to the specifically funerary context, the catacombs, and the many sarcophagi, where the Haemorrhoissa makes her appearance.

In short, to touch the hem is to be embraced by God, His kingdom, and the coming of Christ (Marshall 1989; Luke 6:19 and Acts 5:15, 19:12; Twelftree 1999: 133). According to Ambrose of Milan, this interpretation of the hem is particularly true for the gentiles who will become united in one church, as the church has blood wounds too, but desires to be cured.

But what do we know about the hem in Judeo-Christian material culture? The word kraspedon or fimbria refers to the fringes of the woven border (Haulotte 1966: 65). A fringeless hem would evoke the word limbus. The Book of Numbers (15:38) mentions the tassels or tuft: "Speak to the Israelites, and tell them to make fringes on the corners of their garments throughout their generations, and to put a blue cord on the fringe at each corner." Yahweh commanded Moses the hem bordered all around. These are the so-called Jewish Tsi-Tsit. The Jews would count the words of Yahweh from the numbers of the twisted white threads. It brought to mind the election and liberation of their people.

We should add also that the priests of Israel wore garments without seam-seamless is not to be confused with our issue, hemless (Edersheim 1951). Possession of the seamless garment of Christ, a symbol of the unity of the Church, mentioned in John 19:23 as the chiton arraphos or tunica inconsultilis for which the soldiers cast lots at the Crucifixion, is claimed both by the cathedral 
Figure 10

(a)Healing of the Haemorrhoissa and (b) Peter striking water from the prisoner's wall, fourth century. Milan, S. Maria presso S. Celso. (a)
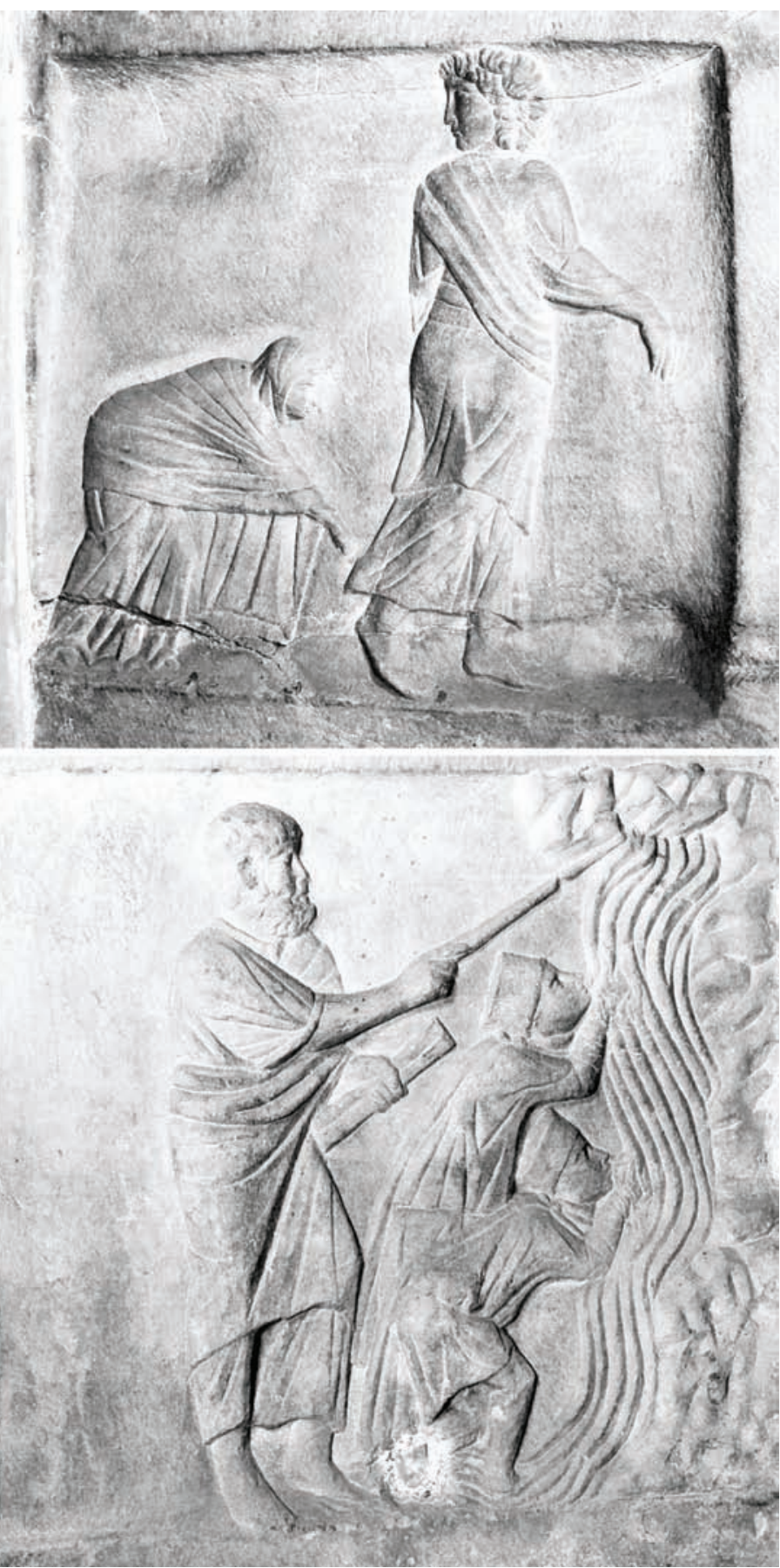


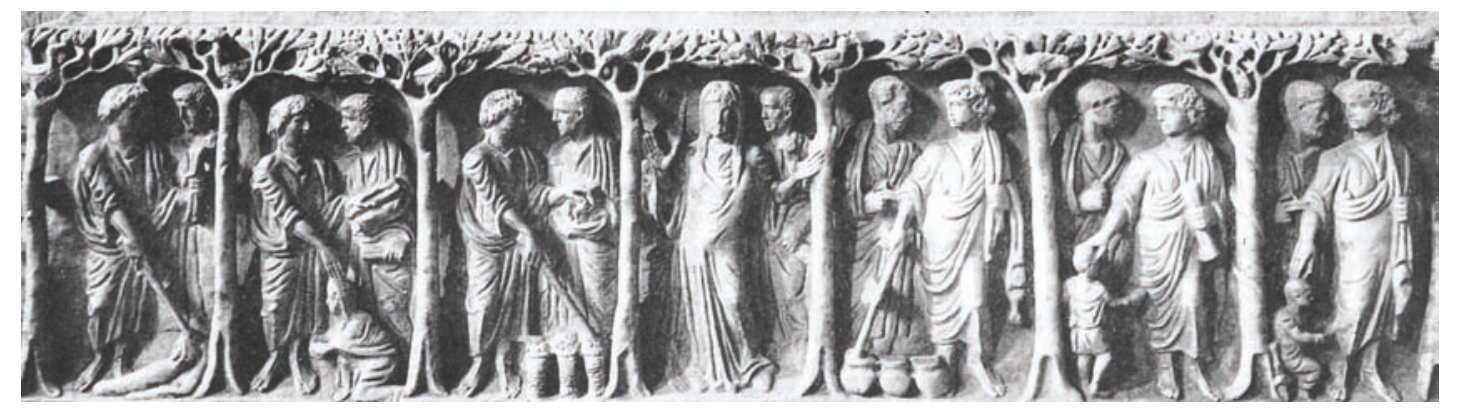

Figure 11

Christ and the Haemorrhoissa, detail from the so-called “Tree Sarcophagus," Gaul, c. 350-60. Arles, Musée Lapidaire d'Art Chrétien.

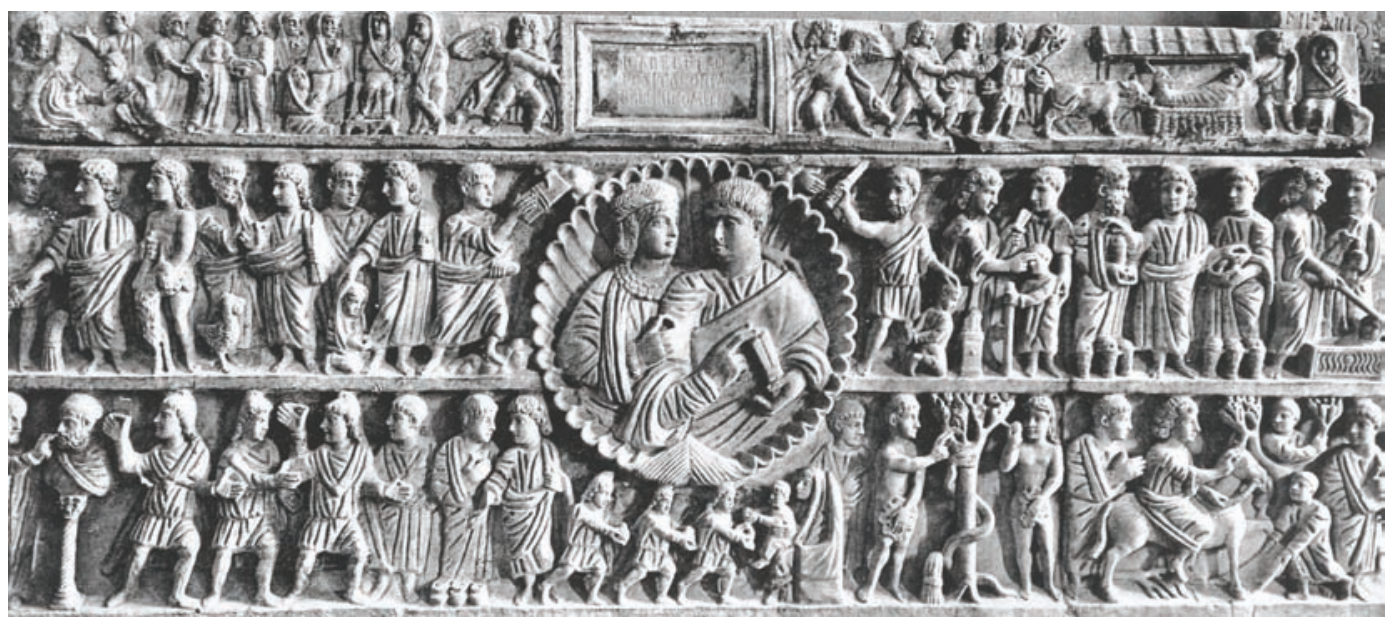

Figure 12

Christus and the Haemorrhoissa, detail from the sarcophagus of Adelphia and Syrakus, Rome, c. 340. Syracuse (Sicily), Museo Nazionale.

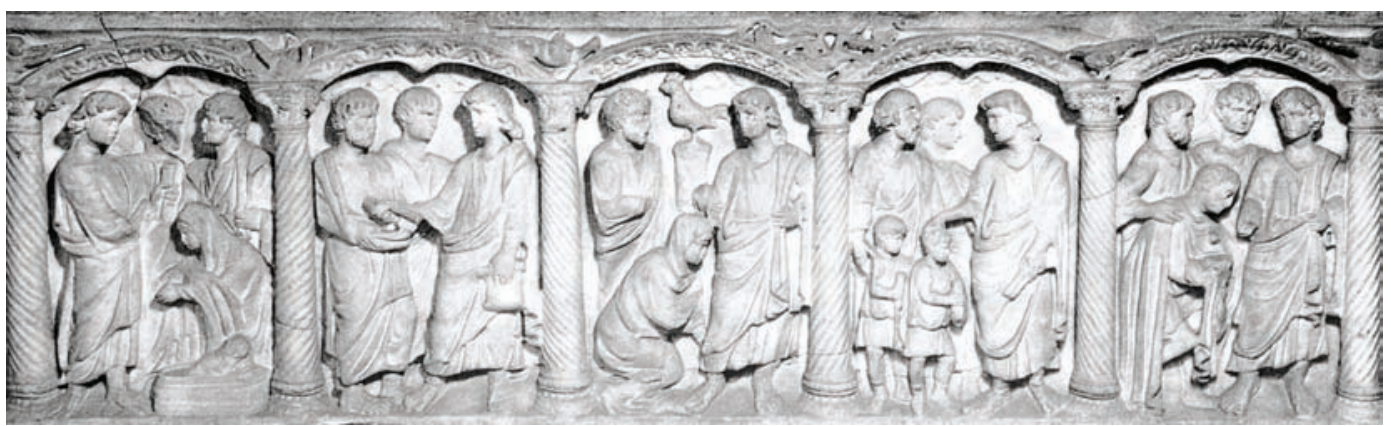

Figure 13

Christus and the Haemorrhoissa, detail from a sarcophagus, marble, h: $63.50 \mathrm{~cm}, \mathrm{w}: 21.15 \mathrm{~cm}$, Rome, 39. Leiden, Rijksmuseum van Oudheden, inv. no. Pb 35. 
Figure 14

Christ and the Haemorrhoissa, wall painting in the catacomb of SS Peter and Marcellinus, third century. Rome

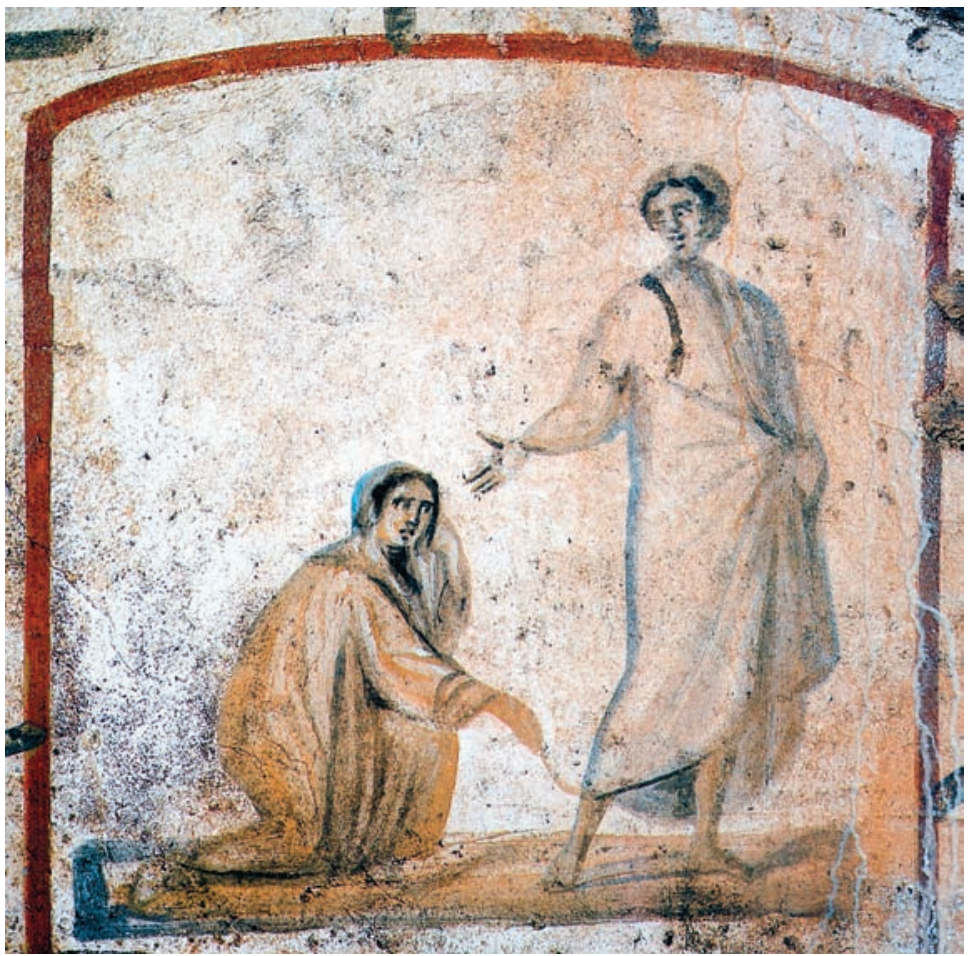

and Hellenistic fashions then in vogue in Rome. Nevertheless the hem remained a meaningful part of textile, vibrating at the border between symbolic language and effective actions.

In any vestimentary culture, borders (such as hems, tassels, but also lace) fragment and defragment the sensitive symbolic markers of the body: the feet, the middle, the neck. ${ }^{21}$ The lower hem of the garment is a border between one's own body and the body of the other. The hem is moreover the entrance and the exit of power par excellence, uploaded as it were, with the idea of the very transfer of dynamij in the story. This symbolizes the hem as a liminal zone where transfer and transpositions become potent between the "I" and the "other," between me and you. ${ }^{22}$ Finally, the hem is also a thriving contact made with the earth. The hem therefore equates with the symbolic meaning of the foot, evoking sand, earth, filth even, in short, the expressions of humility and contact with the Lord (Verhoeven 1956: 166f.; Dr Aigremont 1909: 21). That humble contact at the Lord's service leads to the textualization of textile. Bordertexts are added precisely at these symbolic edges, transforming them into transit zones of plea, praise, liturgy, glory, tears, joys and submission, connecting textile with medieval textacy (see Gandelman 1986: 107-12 for hems as textbearers).

Finally, concerning the cultic meaning of the hem, one particular ramification is of importance for our story. Plutarch (AD 46-120) writes of 
the emperor Sulla: "As she (Valeria Mesalla) passed on along behind Sulla, she rested her hand upon him, plucked off a bit of nap from his mantle, and then proceeded to her own place. When Sulla looked at her in astonishment, she said: 'It's nothing of importance, Dictator, but I too wish to partake a little in thy felicity"' (D'Angelo 1999: 98; Lalleman 1997: 358; Theissen 1983: 134). And she did, becoming his fourth wife. Secretly pulling a thread had to be excused. She fears to be regarded as demonic. On the other hand he actually believes that the textile will transfer, will share with her the power of the body that it wore (Plutarch, in Theissen 1983: 134).

The similarities between the classical anecdote about Sulla and the Haemorrhoissa are striking. Also on the visual level, late-antique connections can be recognized in the emperor's restitution iconography. This iconography consists of an upright statesman with a kneeling, often female personification of the province whose gesture expresses a clementia or supplication.

David Knipp in his Christus medicus in der Frühchristlichen Sarkophagskulptur recognizes a Hellenistic interference, an ekphrasis in the paleo-Christian Haemorrhoissa. One of the five Haemorrhoissas in the catacomb of Peter and Marcellinus has caused confusion given the peculiar line between the hand of the woman and Christ (Figure 14). If this is a remnant of the Sulla story, which it really seems to be, then the mural demonstrates the highly hybrid character of first-century iconography. This is what Moshe Barasch would call "energetic inversions" (Barasch 1987: 170). Energetic inversion is the power of attraction that a gesture-natural or conventional-is capable of exerting over the collective memory of humanity, even to the degree that it becomes a formal-artistic recipient for various emotions and their shifting interpretations across the history of art.

The borders of the cloth circumscribe the body in space. As contour of the body they write the body in their embodiment in time and space. The hem, moreover, emphasizes the body's gravitation; it links the body also to the earth, as feet do. This brings me to my second level of textilization.

\section{Textile and Cloth as Pictorial Metaphors and Embodiment} It may be clear by now, that our healing story is a healing in which textile forms a transmitter of power. But also the garments of the woman herself are particularly interesting. In this second level of textilization, I want to investigate how textile and cloth operate as pictorial metaphors and how they embody the meaning in the visual medium. It is worth noticing that the Haemorrhoissa is often represented enwrapped in clothing, as if she disappears in her own garments. This might point to her feelings of shame, her secret desire, and her being outcast. In fact in some interpretations this is also expressed in the small size of the woman, as in the bible of Otto III combined with the story of Jairus (Figure 15). The Haemorrhoissa is literally banned to the outer limits of the composition of the miniature. An outcast image in the image. 
Figure 15

Healing of the Haemorrhoissa and the daughter of Jairus, miniature out of the Gospel of Otto III, Reichenau, end of the tenth century. Munich, Bayerischen Staatsbibliothek, Cod. Lat. Cim 58, fol. 44.

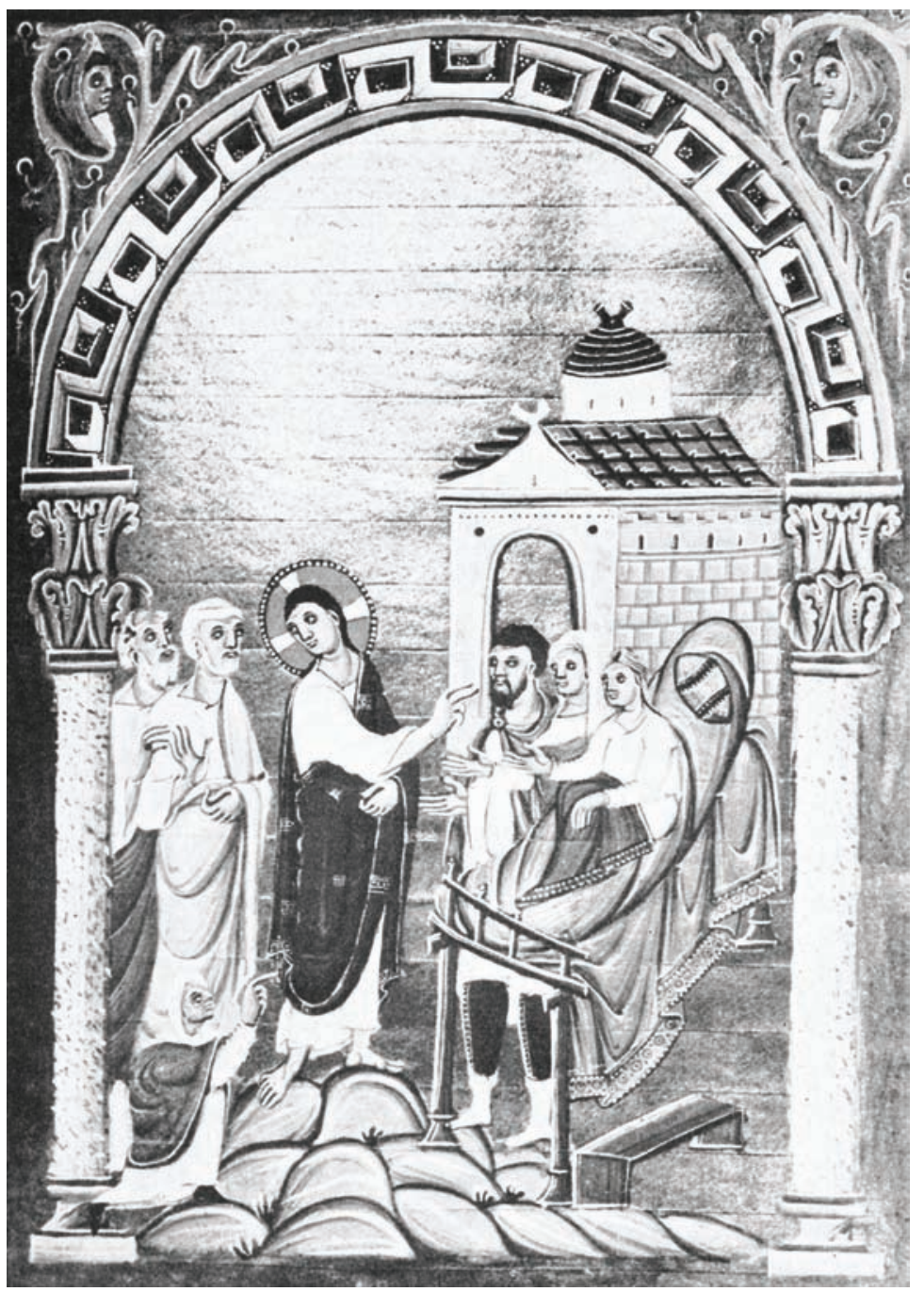

She is crawling formless matter that Jewish audience, the author tries seeks to become whole and healed in form. Some scholars point to the fact that this Haemorrhoissa forms the bridge between Jairus, the Old Covenant, and Christ, the New Covenant. This evokes again the authentic interpretation of the shift from Leviticus to a new era, with new rules, where the doomed are embraced.

In the Didascalia Apostolorum, a Syrian text from the third century, which is clearly addressed to a to convince Jewish converted menstruants not to isolate themselves but to come to church. I quote the Didascalia: "Because also she with haemorrhages who touched the hem of Christ's garment was not isolated, but worthy to be forgiven of her sins" $(26,62,5) .{ }^{23}$ However, until well into the fourteenth century, contemporary with the mosaics in the Kariye Djami, the clergy would fulminate against menstruants 1995: 171; Underwood 1966: 72-4). 
Figure 16

Christ and the Haemorrhoissa, mosaic, fourteenth century. Istanbul, Kariye Djami.

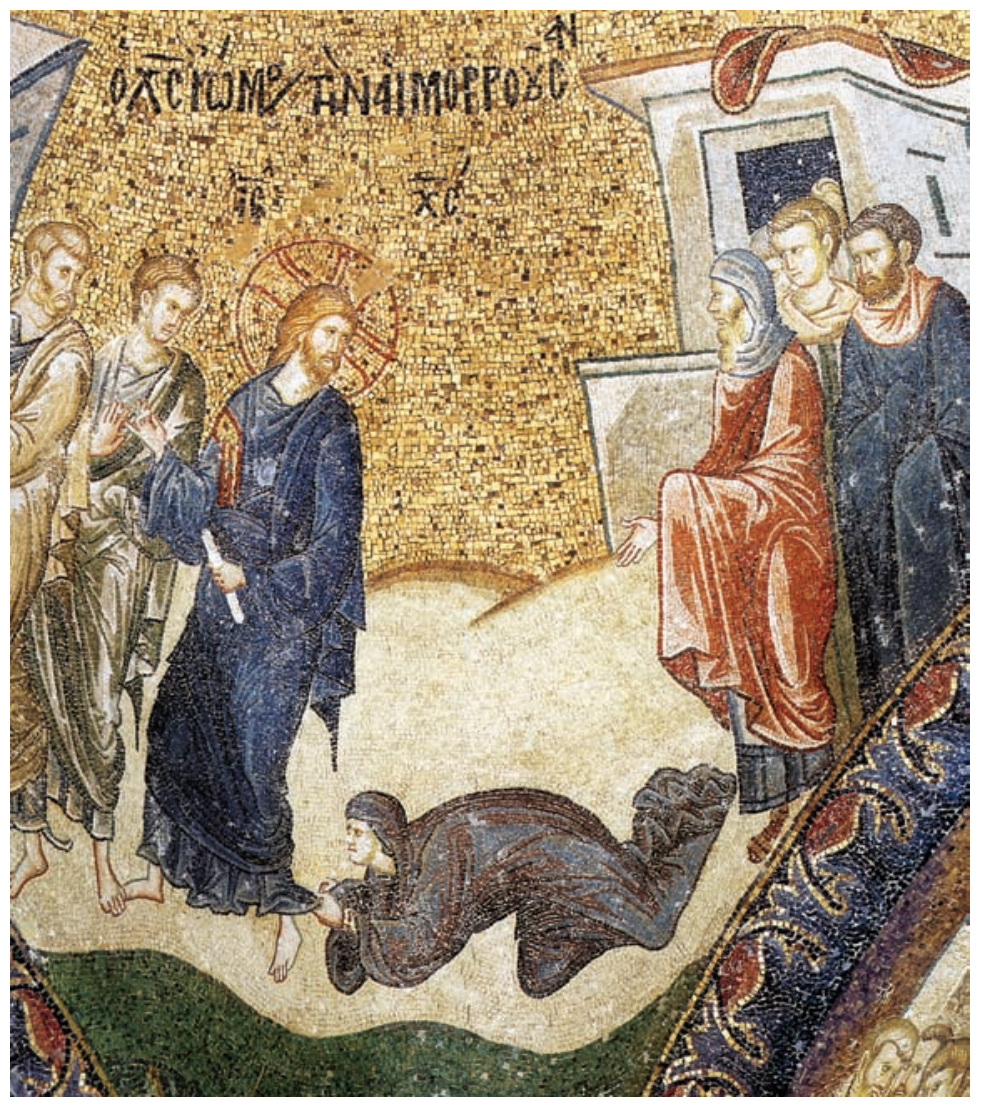

entering sacred space. Mattheus Blastares of Thessaloniki says in his canon laws (Syntagma, 1335): "The woman with a flow of blood did not even dare to touch the Lord short of the border of his outer garments." 24

A strong opposition between female fertile and messianic sacred blood, between the female body and the sacred space is born and will meander through the Middle Ages. This, of course, opens the gendered blood research fields of, among others, Joan Branham and Caroline Walker Bynum. It is a field I will pass by. ${ }^{25}$ Suffice it for the moment to say that all this seems to saddle the Haemorrhoissa with an almost unbearable tension: her bloody presence in the sacred and liturgical sanguine spaces of catacombs and churches. One Haemorrhoissa in the catacomb of Peter and Marcellinus is positioned next to the agape with a female servant. In the Kariye Djami, she appears in the cupola above the Eucharistic altar. The paradox dissolves in the interpretation of the touched hem as the gesture that opens the heavenly Jerusalem, given the symbolism of fluids, of water and of the Eucharist on the one hand, and given the fact that the woman-also according to Ambrose (339-97)-is the embodiment of strong faith, of pistis. Ambrose says: "The likeness of the church is that woman who 
went behind and touched the hem of Thy garment, saying within herself, 'If I do but touch His garment I shall be whole'. So the Church confesses her wounds, but desires to be healed." ${ }^{26}$ Whoever believes can rightly be called the hem of the church, concludes Ambrose.

\section{The Role of Textile in the Material Culture of the Haemorrhoissa}

In his catalog of Early Christian gems, Jeffrey Spier discusses a crystal in which the Haemorrhoissa is represented at Christ's feet (Figure 17). In his article Medieval Byzantine Magical Amulets and Their Tradition, the same author considers a silver intaglio (New York Metropolitan Museum, $5 \mathrm{~cm}$ ) in hematite with on the one side the Haemorrhoissa and on the other an orant, probably Mary (Figure 18; Spier 1993: 44, Fig. 6b, 1917, sixth-seventh century). ${ }^{27}$ The epigraphy refers to the chapter in Mark (Frazer and Weitzman 1977: 440). Hematite, or bloodstone, has a red radiance that becomes black when it oxidizes (Meier 1977: 392-5). It was thought to be petrified blood, and from a medicinal point of view it was used to treat dangerous blood flows. The medieval mind recognized in the word etymologically haimatithenai-"blood that stops." ${ }^{28}$ The fourth-century Orphica says that hematite was formed when the blood of Chronos dripped down on the earth: A leech come down from heaven (Abel $1885 \mathrm{mp} .131 \mathrm{n}$, verses 642 and further; Barb 1948: 67).
Another amulet preserved in a private collection combines the Haemorrhoissa with a snake's head (Figure 19; Spier 1993: 44). ${ }^{29}$ The gem introduces the hysteria motif in connection with the hemorrhage (Veith 1965). The snake's head is the portrait of the uterus. The portrait will protect her, calm her down (Pointon 1986). In fact the uterus was considered an animal difficult to tame, that has the capacity to swell up, and to shrink. It was believed that the womb could develop tentacles that could take over the whole body, reaching the level of the throat (Leyerle 2001; van L00 2007: 112-13).30 In the lower material world of gems and tokens the passus in the Bible becomes the flipside of the intrinsically spasmodic character of the uterus and its phantasm of the
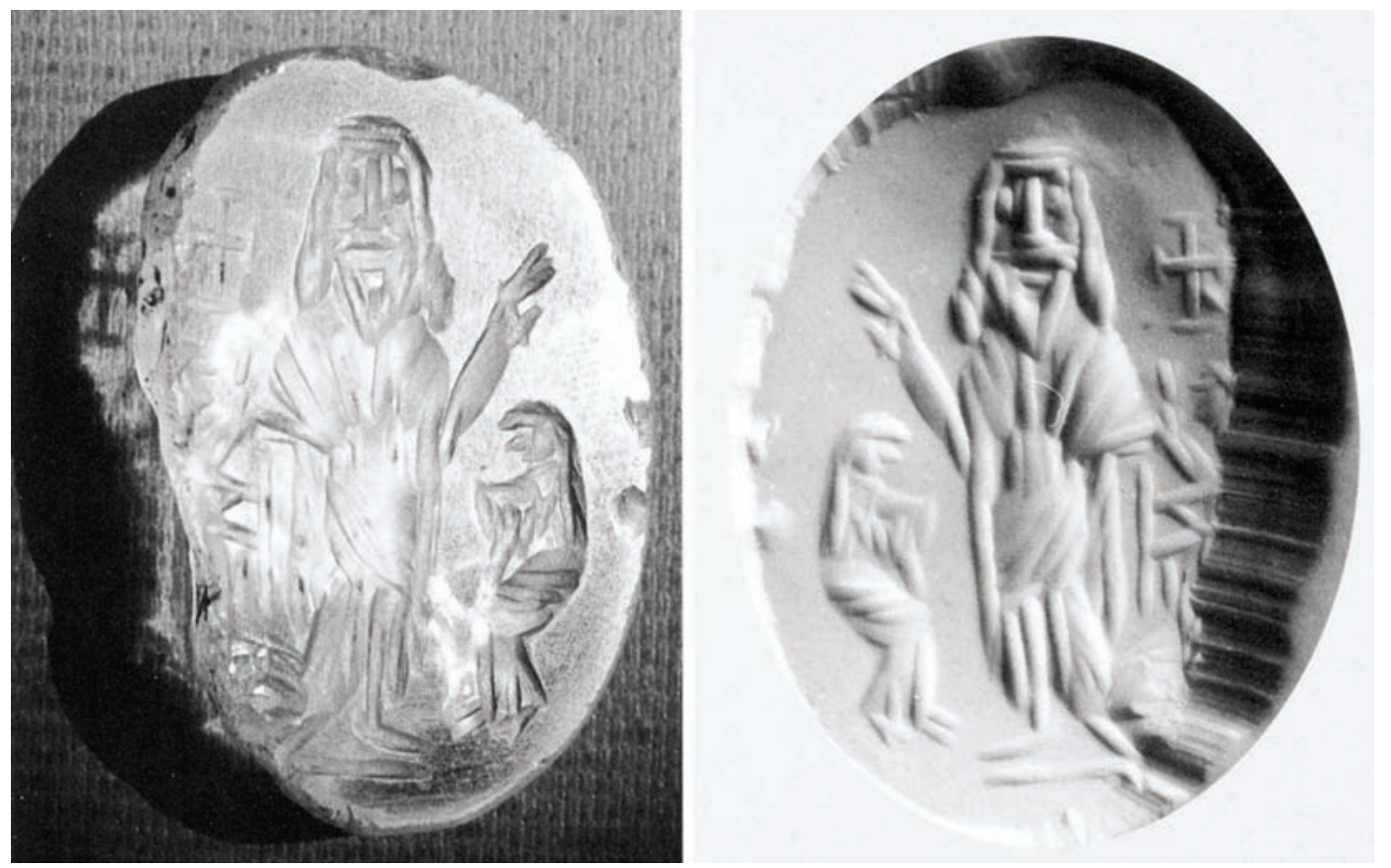

Figure 17

Amulet, crystal. New York, American Numismatic Society, inv. 307. 
Figure 18

Hematite amulet with the healing of the Haemorrhoissa, Egypt, late antiquity. New York, Metropolitan Museum of Art, 17.190.491.

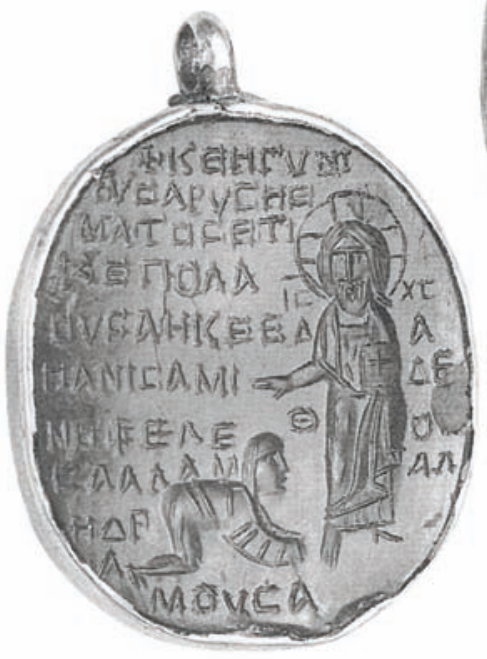

Gorgo or Medusa. More strongly put: the Haemorrhoissa is the uterus. She is hematite, animated by the intaglio that inscribes the healing power on the body.

Being born in a textual world, then entering the iconic world and the liturgical space, the Haemorrhoissa, finally, sank into the performative world of magic and body art. In that world, she actually returned to the liminal zones of tactility, the body, and the magical object worn on or under textile.

\section{The Textile Motif and the} Haemorrhoissa in the Debate on Cult Images

My final point treats the textile motif as impetus of the Haemorrhoissa's ramifications into the realm of the debate on cult

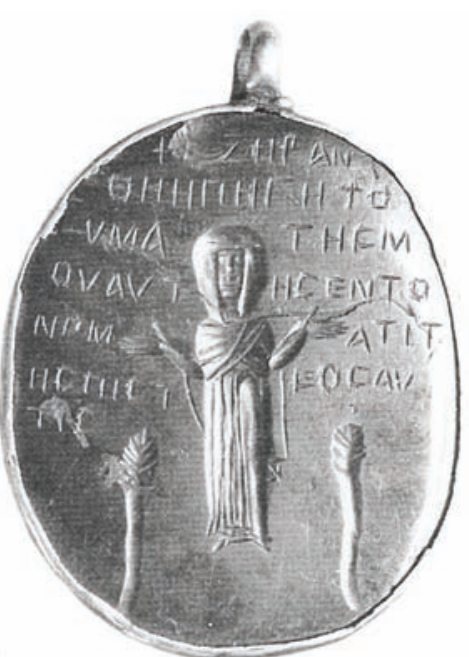

images and acheiropoietoi or how textilization finally interweaves with the "iconization" of paleo-Christian culture.

An important source in that regard is Eusebius' Ecclesiastical History, book 7, chapter 18 (Eusebius of Caesarea 1955: 191-2; see also Bugge 1975: 127-39; Fabre 2007: 229-51; von Dobschütz 1899: 31, 197):

1. Since I have mentioned this city I do not think it proper to omit an account which is worthy of record for posterity. For they say that the woman with an issue of blood, who, as we learn from the sacred Gospel, received from our Saviour deliverance from her affliction, came from this place, and that her house is shown in the city, and that remarkable memorials 
Figure 19

Amulet with hysteria motif. Private collection.

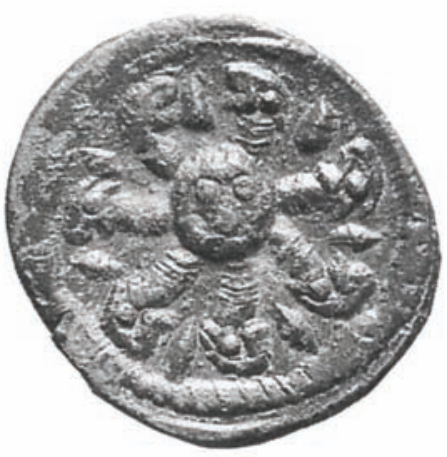

to those regarded by them as deliverers.

The statue in Paneas is also mentioned in a homily of Basil the Great (329-79), bishop of Caesarea..$^{31} \mathrm{He}$ specifies that Maximinus removed the statue, and that the statue was a speechless image animated by a miracle. And last but not least: Basil gives the Haemmorhoissa a name: Berenice. Berenice is also her name in the Acti Pilati (after 375). These Acts recount that when Christ went to the house of Pilate the twelve standards with the images of the emperor bowed to Him. In the same passage Pilate asks for witnesses for Christ's trial. One uninvited woman, Berenice, shouted her story from a distance in the crowd. The Jews, however, refuse her oral and female testimony. Berenice would refer to the carriers of the banners, pehre-nike. The twelve standards refer to her twelve years of illness, and also here she is hidden in the crowd. What is also striking is the introduction of miraculous images (Kuryluk 1991: 119-20). The image cult of the ancients begins to shift towards, to bow to the new image cult of Christianity.

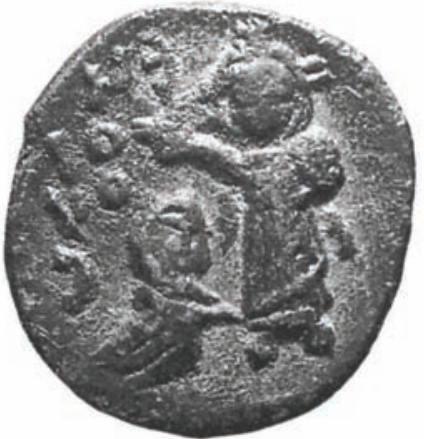

Philostorgius (368-430) ${ }^{32}$ says in his Historia Ecclesiasticae, VII, 3 that the people of Paneas honored a statue of Jesus that was placed near a fountain on the market place by the hemorrhaging woman herself (Wolf 2002: 287). He adds that this place was very suitable for a woman that suffered from her menses. It was, however, destroyed by Julian the Apostate (361-3) (von Dobschütz 1899: 94). Philostorgius mentions that a head with a golden glow was preserved and venerated in the city. A sixth-century pilgrim reports on a golden-bronze image, but after that the object disappears from the testimonies.

The story of the statue in Paneas marks the transition in iconic systems. Eusebius and Basil hold different opinions. Eusebius is wary of the veneration of images by Christians. Basil, on the contrary, sees the image as a moving testimony to a miracle. And the later important defender of image cult and veneration, John Damascene (676-749), refers to the statue of Paneas as an argument for iconophilia.

Further legends embroidered based on the Acti Pilati or Acts of Pontius Pilatus. ${ }^{33}$ From the fifth to the eighth century the Cura 
Sanitatis Tiberii took form, probably arising in Northern Italy (perhaps Tuscany), closing the circle of Haemorrhoissa-BereniceVeronica. ${ }^{34}$ The legend relates how the Roman Emperor Tiberius, seriously ill, had heard of Christ. He decided to send for this healer/ Savior. Volusianus, a high imperial official, was sent out, and reached Jerusalem after a year and three months. Pilate and the Jews were terrified by the summons, as Christ had in the meantime been crucified. The people blame Pilate and he is imprisoned. Then Volusianus hears of a woman from Tyre who was cured of an issue of blood by Christ, and had an image of him made. He sends for this woman, examines the image, and orders that everybody implicated in Jesus' death be killed. He then takes Pilate, the healed woman, and her image, with him on his return journey, but banishes Pilate from Rome. Upon looking at the image of Christ, Tiberius is cured. An eighth-century gloss identifies this anonymous woman as Veronica. 35 "The legend combines the Acts of Pilate with the legend of Paneas. The Paneas legend speaks of a statue, while the Cura Sanitatis Tiberii suggests an icon. It is possible that the Cura Sanitatis Tiberii adapts the nature of the portrait in order to make it transportable" (Kusters 2009). Furthermore, from the sixth century onwards the Syrian Legend of Abgar was spread, recounting how the king of Edessa was, in a similar fashion, cured of leprosy thanks to a cloth bearing the imprint of Christ's features: the mandylion (Wolf et al. 2004). All these tributaries feed into the Roman Legend of St Veronica. In the twelfth century the first testimonies occur of a sudarium. ${ }^{36}$ Gervase of Tilbury mentions an image secundum carnem, apparently a bust painted by Veronica and preserved in San Pietro (von Dobschütz 1899: 292). Gerald of Wales says that he saw in Rome a veil (peplum) with the imprint of Christ's face (impressit): vera icona, id est, imago vera. According to the same author, nobody saw the actual image since a veil (vela) hung before it (Cambrensis 1873: 274ff.).

To return to the statue of Paneas, most probably the statue was a late antique group, adopted by the Christians with a new content. Thomas Mathews, in his The Clash of Gods, shows a coin with Hadrian and Judea in analogous postures: the kneeling, the outstretched arms (Figure 20; Mathews 1993: 62, Fig. 42).

Because of the mention of a tonic plant in Eusebius' account, some authors presume that the statue originally represented Asclepius, perhaps with his daughter Panakeia who, according to the story, searched and found a healing plant (Eisler 1930). This would mark a second transition: the transition from Greek herbal therapy into the miraculous healing by Christ.

In sixth-century Greece and Mediterranean Italy, incantations mention the herb berenikij that has many healing powers. In the same group of charms berenikij is related to blood demons. "So thou too stop the blood of the servant of God, congeal disease, as that one and as a Stone, may it be annulled. I exorcise thee by the Faith of Beraioonikij blood, that you may not drip further; let us stay good, let us stay in fear; amen. 
Figure 20

Coin with Hadrian restoring Judea. Naples, Museo Nazionale.

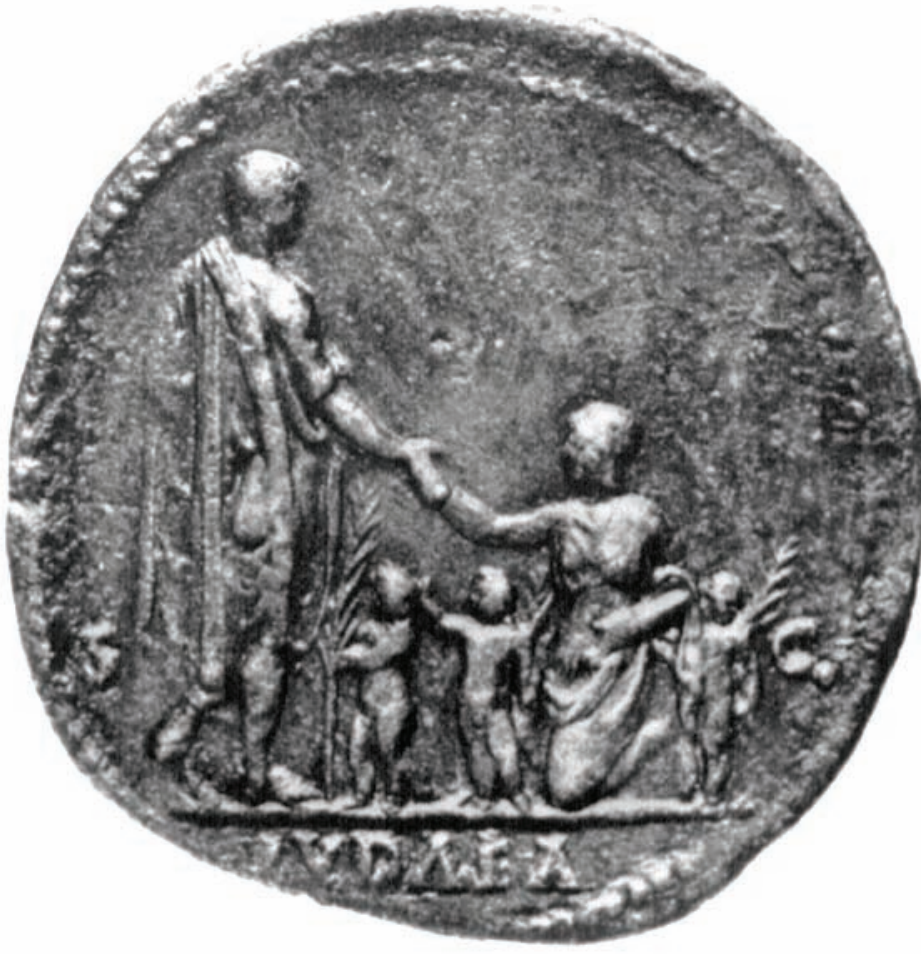

edge of the love bed, and thirdly, a border plant. 39

38-42; Ebermann 1903).37

Botanists have traced the plant back to Persia. It is indeed a socalled border plant that prospers in dry, rocky ground, under the name veronica chamaedrys or spicata. In English cottage gardens it is still to be found under the name speedwell..$^{8}$ Indeed the herb was said to have a tonic effect on blood. Whatever it is, the officinal herb described by Eusebius, climbing up from the socle, over the feet to the hem of Christ, seems to mirror the Haemorrhoissa herself: creeping, crawling, clinging to the earth, but moving towards that desired powerful hem. And is it not remarkable indeed, that the Indo-European linguistic root of the hem-bherem-besides to seam of cloths, common to the bank, the

\section{The Anthropological Space: Threads and Roots}

At this point, we have reached deep archetypical contrasts between living herbs and inert dead metal, between flux, such as the pouring hot metal and the fountain on the market, and the dry counter-flux in the statue and her healing. These metamorphoses in nature are the fundamental principles of pre-medicine cosmology. "Living in close contact with plants and animals, the pre-modern human being had developed a three dimensional system (if we add rocks and minerals, we might say a four-faceted system) in which creation (or, if you will, the existence - everything organic, animate, living, and sentient) lived together in the interaction of an ongoing exchange of perceptions, information, and fluid or ethereal substances" (Camporesi 1995: 88 ). We have seen that in this context, the hem is a universal vibrating transit symbol that, besides the nature of "water" and "plant," remains connected with the very border of the textile. From the narrative and the iconic space, my reading of the hem is as the symbol of demarcation and discontinuity. This discontinuity was part of the healing miracle: a flow was stemmed. The syntax of the interruption was translated into the medium and the symbol of the hem. However, the hem as "discontinuity" is not solely a rupture, but also a locus of exchange: the locus of the transit of 
power (dynamij) from one person to another.

In this last phase, we touch a methodology that goes beyond iconographical and literary sources, but departs from ethnographical knowledge to reach the deepest archetypes.

Three angles will be adopted: the semantics of the hem and its link to generative capacities, the cosmology of gnosis and the cosmogonic womb, and the anthropology of the textile arts as a lead to an increasing iconization of a uterus phantasm. From these three angles I will approach the point of intersection between the Haemorrhoissa and Veronica, to whose figure the woman with an issue of blood was assimilated during the Middle Ages. For is the fundamental question not: how could touching the hem of Christ's garment lead to the woman who carried the imprint of Christ's face? An answer is possibly to be found in the anthropological interweaving that displays itself between the Haemorrhoissa, the touch of the hem, the uterine blood, and the emergence of visuality.

In her Saum und Zeit, Ellen Harlizius-Klück builds from a metonym: the interpretation of the body of the Virgin in light of her theological significance as origin of the era of the New Covenant and the location in which the Incarnation took place. $4^{\circ}$ These semantics link the hem as the visual contour of the body, and the concepts of time and space. Within this analogy, the hem acquires the force of a pars pro toto. The contour of the body itself forms a temporal and spatial "perigraphy." The power of the concept of the hem is also apparent from the many linguistic prototypes and offshoots. Harlizius-Klück's research grew into a lexicon, with the author tracing, amongst other things, the Hebrew denotations that connect the hem to the bosom and, more importantly, the womb.

Heik is the Hebrew for both hem and bosom. The bosom is understood as the marked opening in the cloak, just above the belt (Is. 40:11, Ps. 74:11) (HarliziusKlück 2005: 94-5). Kanap means wing, cloak hem, hem, edge, but also lap and womb. It is related to the cloth that covers the private parts (Deut. 23:1; Deut. 27:20). In Ruth 3:9 the taking of the father's wife is compared to the taking of the father's blanket or cloth. It is, indeed, this root that led to the typical Hebrew cloak-in fact a draped blanket-with the tassels already discussed: the Tsi-Tsit. As has already been said, this cloak/cloth brings to mind Yahweh's commandments and the tassels relate to the laws of the Old Covenant (Num. 15:38; Deut. 22:12) (Harlizius-Klück 2005: 105). Sul is the hem of Yahweh's royal garb. Isaiah $6: 1$ says that the hem filled the Temple. The word also refers to the edge and circumference of the pitcher, in its turn an image of a woman's lap. The pitcher is a universal symbol for the preservation of the mystery and the metamorphosis that will take place (Lurker 1991: 232-3; Neumann 1956, 51ff., 123-46). The vas is an image of the womb in both form and usage. The Song of Songs sings "Your navel is a rounded goblet” (7:2) (Baert 2006: 35-62). In combination with the verb galahn, Sul is to uncover (Jer. 13:22, 
25-6). To uncover the hem implies revealing a vulnerable part of the body (Nahum 3:5) (Baert 2006: 187). This explains why the hem is also related to erotic feelings and feelings of shame. In the Legend of the True Cross and the Queen of Sheba, we still encounter traces of this. In a rhymed German version by Heinrich von Freiburg, dating from 1275, we read:

Da beugte sich die Herrscherin, kniefällig betend fiel sie hin, und Lüftete den Saum der Kleider

mit blossem Fuss, den sie enthüllt.

Darauf sprach sie, vom Geist erfüllt,

demütlich das haupt gesenkt, und zu sich selbst dazs Wort gelenkt:

Das Zeichen des Gerichtes ward vor meinem Blicken offenbart.

(Beyer 1987: 242)

Then the queen bowed, on her knees she fell and lifted the hem of her dress and a naked foot she unveiled. Then she said, filled by the

Ghost,

Her head so humbly, and she spoke to herself: the sign of the Judgment has appeared before my gaze.

The "unveiling" of the foot by the hem, is immediately followed by the "fulfilment" of insight. In a subtle manner, the author links the mysterious disclosure of the foot with eroticization, humility, and revelation.

The Hebrew roots of the concept of the hem provide a number of links connecting the covering of the most intimate, to the womb and by extension to sacred space. For Harlizius-Klück this indicates that in its earliest form the hem was not a circumscription in the meaning of a discontinuity, but in the sense of the world's "circumference," and thus related to the continuous and to eternity. In its authentic semantics, according to this author, the hem therefore has a much more spatial than temporal texture. In Ellen Harlizius-Klück's words:

Die These ist, dass die Bedeutungslage des Saumes als Schnittkante, Rand, Marginalie und Diskontinuität und die der Zeit als konstante, kontinuierliche und ordnende Kategorie ehemals umgekehrt war: Der Saum stand für den ordnungsgebenden Anfang und die Kontinuität der Tradition; die Zeit wurde wahrgenommen in der Form eines Einschnitts, der Wunden im Leben erzeugte, die es durch bindende Gewebe zu heilen galt. Es stellte sich im Laufe der Untersuchung ein Motiv heraus, and dem sich die Umkehrung am besten darstellen lässt, das aber als begriffliches Instrument in den konsultierten Wörterbüchern fehlt oder als Randerscheinung angesehen wird: der Saum als genealogischer Ort. (HarliziusKlück 2005: 5-6; emphasis added)

The hem refers to the place of (pro) creation itself: the womb, the space of the holy of holies. As a locus, the hem frames a time that is felt as a wound, an opening, and a cut in the fabric. ${ }^{41}$

From the perspective of Ellen Harlizius-Klück's Saum und Zeit we can therefore derive a new hermeneutics of the hemorrhaging woman. $4^{2}$ The Haemorrhoissa touches the hem: the very matrix of time and space. The wholeness of the healed Haemorrhoissa is mirrored in the hem as symbol and image for completeness, sacred space, restored genealogy, and procreation. Her touch is a metaphor for the old verbal images of the womb, the pitcher and the Temple. Her touch is located in the zone of the veiled, and therefore partakes of shame throughout the unveiling. One could say that in this hermeneutic, the hem is the second form of the Haemorrhoissa herself-vase, uterus, shame-but also of Christ-the Temple. It is precisely in the hem as metonym that these connotations flow into a single dynamij that jumps back and forth between Christ and the Haemorrhoissa. According to this hermeneutic, the hem loses its connotation of separating boundary, of "discontinuity" as rupture, and tips into a different type of dynamic, namely one of both sides. 43

In the second approach-the gnosis-we will see that the hem, and by extension the female lap as ordnungsgebenden Anfang (Ellen Harlizius-Klück) entered and spread through the cosmological outline in other contexts as well. 44 In the second-century Gnostic literature the biblical Haemorrhoissa appears under the name Prunice, regarded as the feminine principle of the universe and identified with Sophia, "wisdom," and Mother Achamoth, the "second Sophia," the more negative side of true wisdom (Kuryluk 1991: 107-11). 45 Prunice's flow was seen in analogy and contrast to 
the flow of Christ's blood; the divine emanations as seed and Prunice's flow as procreation. In Valentinianus' Gnosticism, known through Irenaeus' treatises (late second century) and Epiphanus (c. 315-402), Prunice is "bearer," the twelve years of her bleeding interpreted as twelve emanations or children. $4^{6}$ The Prunice-mythology reflects the Gnostic idea of a variety of worlds, the so-called Aeons, divine emanations or thoughts, the best-known of which is the Aeon Sophia. For the Ophites she is the emanation of the first woman, mother of all living things and bride of God the Father and the Son, she is responsible for the birth of Christ. 47 "In the Gnostic cosmologies the twelve years of hemorrhage are transformed into the apocalyptic twelve-year passion flood that would-had Christ not come-have destroyed the earth. But when she touched the hemsymbol of the moon's last quarterthe flood was stopped and the world was saved from destruction" (Kusters 2009). ${ }^{48}$

In the suppressed dualistic cosmology of the gnosis, the Haemorrhoissa is anchored in the archaic anthropology of blood: the opposition between menstrual flow and internal blood, between menses and seed, between the feminine and the masculine entity, between unclean blood and pure blood, between negative pole and positive pole (Camporesi 1995: passim). 49 "In both its positive and negative aspects, it represents carnal existence. Menstruation opens the way for the possibility of life in this world and is an apt symbol for the messy flux or mortal flow of life" (Buckley and
Gottlieb 1988: 77). In short, at least in dualisms such as gnosis, the Haemorrhoissa became connected to very old principles of potentiality, restoration, and the unique procreative capacity-paradoxical and anxious-of the bleeding womb. One need only think that the womb is-besides the nose-the only opening that sheds its own blood (benignly or malignly) with any frequency.

Traces of the matrixial primal principle were expounded by the early Church Fathers. Irenaeus (98-177) says that the descendants of Cain regarded the Hystera (the womb) as their creator (Barb 1953: 210). Hyppolitus of Rome (early third century) also comments on the matrixial cosmogony of the gnosis (Culiano 1987). The womb derives from the first congress of the two principles with the navel in the middle: the microcosmic center, the omphalos. The Uterus is characterized by black (sometimes: "dirty") underground flows. It is the prima or diva matrix, still inert and in a certain sense genderless. The dark water, however, continually desires to be united with the light of the skies. This struggle gives rise to all others, and to gendering. Before the heavens and the earth were created, says Genesis, God's spirit moved over the waters.

Ideas about the diva matrix as "creatress" were still known in medieval Europe. Paracelsus calls dark water-preceding the Creation and uniting itself to the divine spirit-the matrix. In this womb and no other heaven and earth are created, says the sixteenth-century scholar (Paracelsus 1922-33: 177f.). The ancient diva matrix symbolalways with a curve that ends in two 
bulges, whether or not snake-like or spiral in shape, and often similar to an octopus-were disseminated on gems that were known in Europe into the seventeenth century.

We know from N. C. F. Peiresc's correspondence that Rubens owned such a gem (Barb 1953: 194). The art dealers had recommended a Gnostic amulet to his attention: an intaglio d'amethista con la vulva deificata et revestita della le di farfalla. Around the uterus was the inscription THEAZ MHTP (diva matrix). In his reply, Rubens expresses his excitement at the tip and in the margin he even sketches the gem (Figure 21)..$^{0}$

As we have already seen, the Haemorrhoissa gems also fit into this fickle world of the evocation, conjuration, and glorification of the awful uterus. This shows once again that the biblical bleeding woman tied in with patterns of feeling that preceded the composition of the biblical text or could be explicated in alternative genres of the time, such as the gnosis. The biblical narrative guise initially thematized in the synoptic Gospels as a miracle of healing, was sucked into the hidden uterine models from the world of Gnostic cosmology, on the one side, and the material cultural world of magic on the other, where it could swell into a new archetype. This process of recognition and appropriation from the Bible indicate a boundless energy that remained "beneath" the narrative and iconic spaces of the Christian spectrum.

This brings me to the third angle of approach: the anthropology of the textile arts as a lead to the increasing iconization of a uterus phantasm.

One can historically identify a desire to iconically grasp the unfathomable regenerative powers of the matrix or uterus, the impalpable "blackness" of her underground but nevertheless life-bearing flows. This led to both aniconic forms and motifs evoking a feel of this unfathomable potential as well as phantasmatic images increasingly entering an iconic register.

The case of Berber weaving offers an approach to this first issue, and offers one a view on the primal expressions of what would culminate in an iconization of the uterus phantasm (Vandenbroeck 2000: passim). The inner and material culture of Berber women has remained relatively uncontaminated by masculine thought patterns. Their ceramics and textiles furthermore show a symbolic and even proto-symbolic expression that, with minimal "pollution," goes back to the Neolithic. For Berber women, the act of weaving is a cosmogony and a procreation (Figure 22). Weaving itself mirrors the potentiality and power of creation from fluid, dark nothingness. The warp yarns are
Figure 21

Sketch of the gem in possession of Peter-Paul Rubens. From Barb (1953: 193-238, nr. 25d).

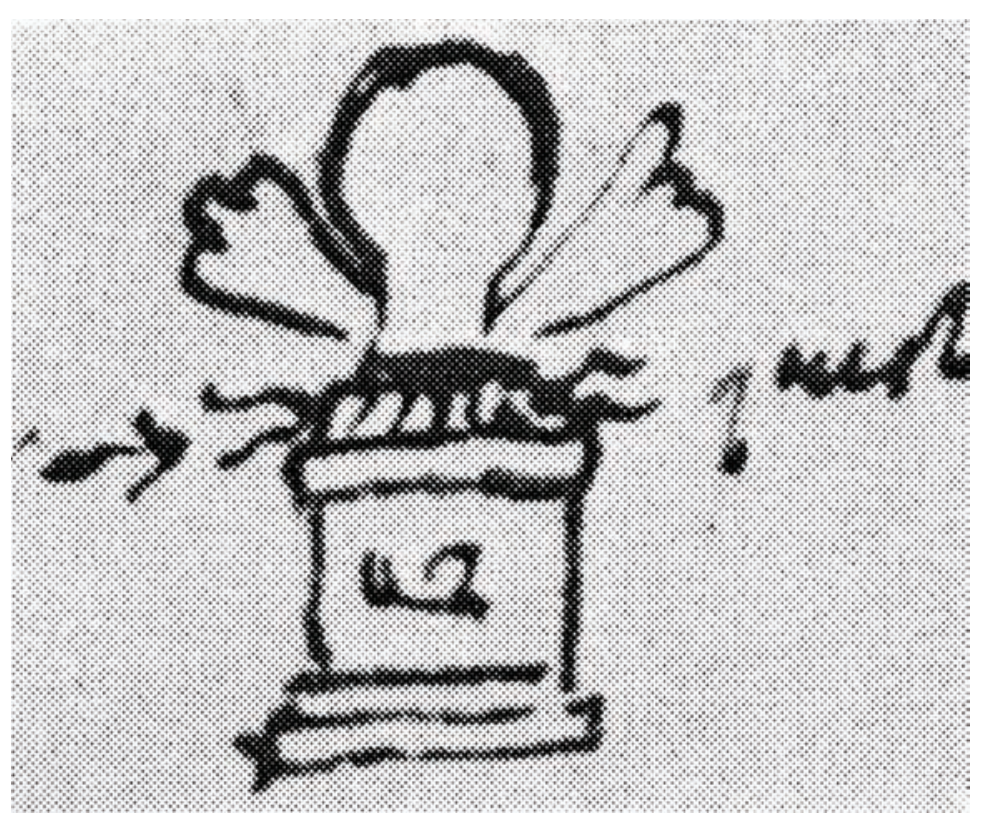


Figure 22

Berber textile, date unknown. Private collection. the axes mundi, and the cutting of them is compared to birth itself, with the cutting of the umbilical cord. The "hems" or fringes that arise are reminders of the separation between mother and child. The colors used are primarily black and red. In this cosmoanalogy of weaving a particular motif is central: the ever-recurring central iconic hollow in the cloth, often a stain-like black spot, a place to which the weave tends, something that pulses in the fabric. Paul Vandenbroeck calls this the "nameless motif." Berber women explain the recurrent black spot as the shuddering spasm of the uterus itself (Vandenbroeck 2000: 114). In fact this "nameless motif" is a prefiguring of the later uterine

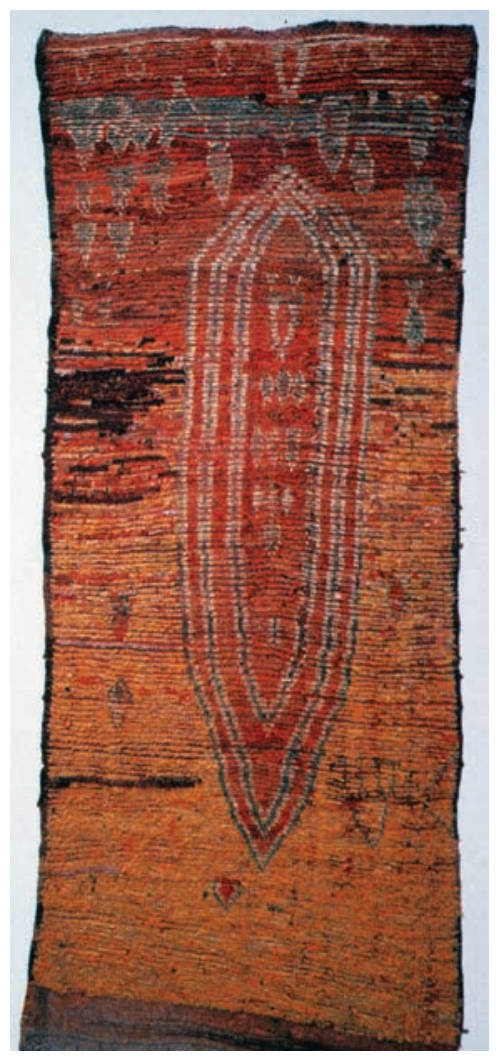

icons, as seen in the gems. The uterine icon as such develops from the amorphous, the fluid, and the stain-like to the figurative. This path goes from a positive fascination to a more fearful one. Octopuslike creatures, for instance, or balls with pins, tentacles like hedgehogs, and snakes' heads are often found as figures of the womb, corresponding to the swelling and shrinking capacity that the womb was thought to have (See also van Loo 2007: 113f.). In the last phase of the growing figuration, it was even given a face: that of Medusa.

The representation of the matrix as a face has its roots in the preclassical pantheons and myths. ${ }^{51}$ The Babylonian mother-goddess Nintu lives in the mountain ${ }^{52}$ and embodies fertility and regeneration. Her face is represented with the abstract sign of the female sex: an arch ending at the bottom with a curl similar to the Greek letter Omega (Figure 23; Barb 1953: 199). The same shape-schematized from the female anatomy-also appears for the Egyptian mothergoddess Hathor (Figure 24). As a hieroglyph the sign means "protection" (Murray 1911). 53 There are archaeological finds that suggest the possibility of Medusa being assimilated to Hathor (Nintu) (Pettazzoni 1921). An Etruscan terracotta from Campania shows that the apotropaic face is placed within the omega-scheme with a shell as background (Figure 25). In brief, a route can be traced from black formlessness to schema to zoomorphic symbol (octopus, hedgehog), and from the animal to the anthropomorphic.

The Medusa with snakes for hair, but also the Haemorrhoissa 
who joins Medusa on the medieval flux and face, between textile and gems, forms an extreme stage of the Medusa, becomes bridgeable. An increasing iconization of the uterus phantasm. Thus the apparently immeasurable distance between

Figure 23

Babylonian relief showing Nintu. From Barb (1953: 193-238, no. 27c).

Figure 24

Symbols for Nintu and Hathor. From Barb (1953: 193-238, no. 28c). impressive continuity is revealed between the fluid blackness and the apotropaic face of the diva matrix.
This perhaps identifies the point of intersection between the woman who touched the hem of Jesus' garment and the woman who would carry the face of Christ.
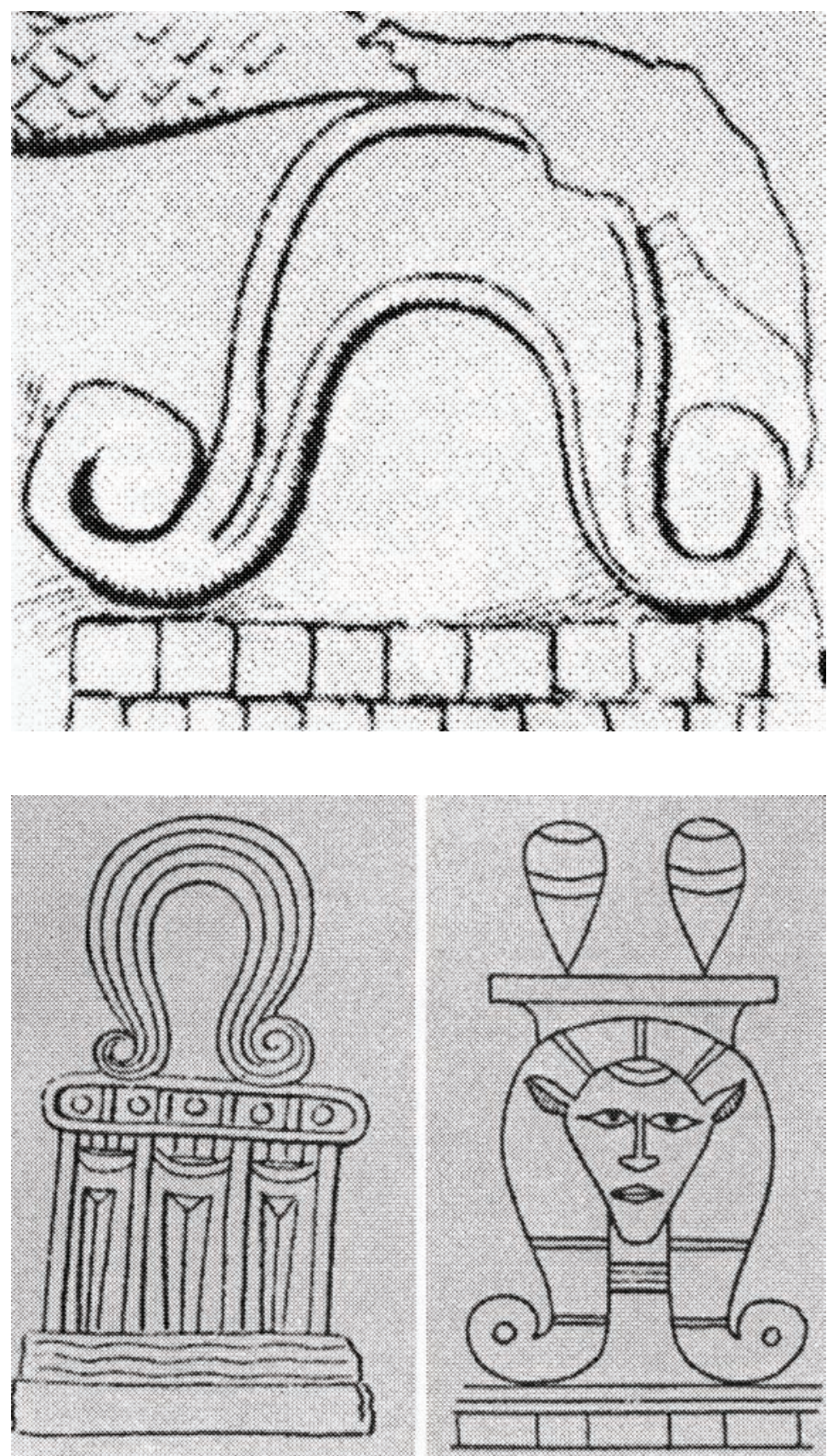
Figure 25

Terracotta showing "Medusa," Etruscan, c. 500 BC, Campania. From Barb (1953: 193-238, no. 33a).

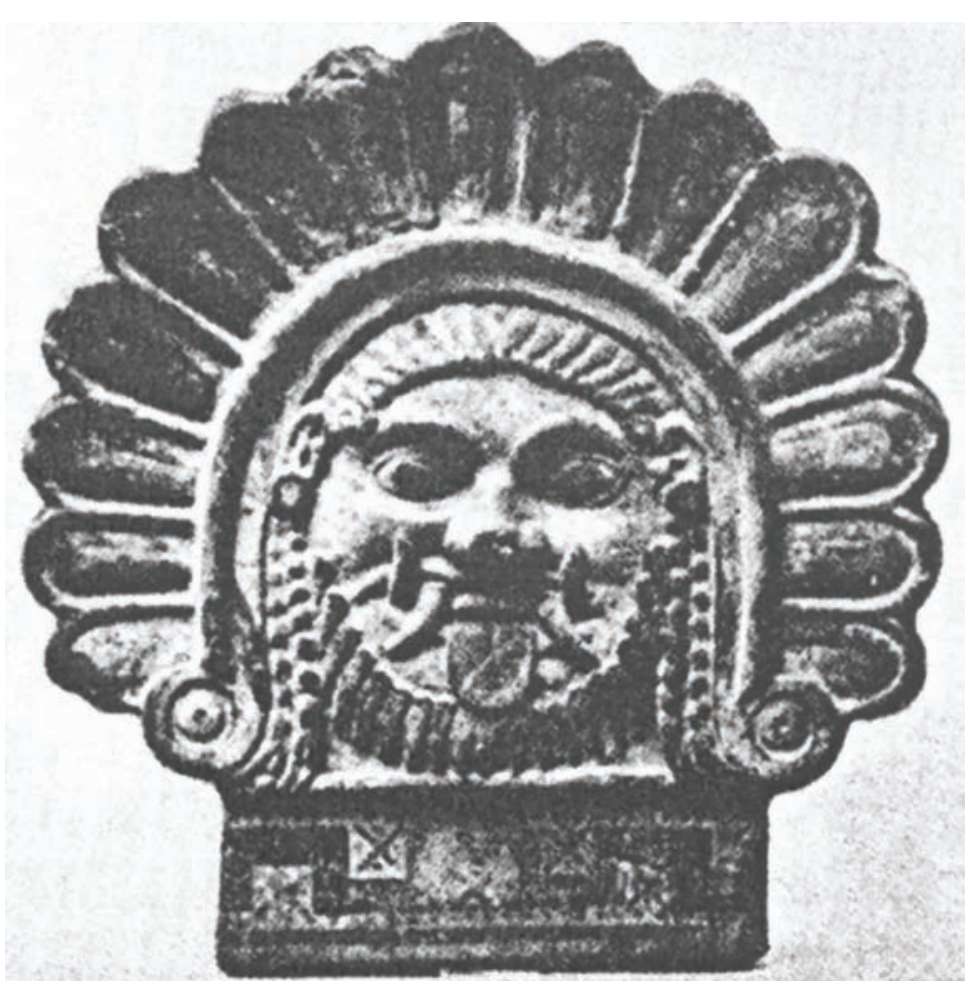

At a micro-level we have already seen how in the third century the Haemorrhoissa was given a name-Berenice-and that from this naming, traces were drawn between a woman cured miraculously and a specific witness during the trial of Pilate. In the Acts of Pilate this woman is put forward as the source of the iconic witness to Christ. At this level, the Haemorrhoissa can be read as the starting point for the defense of a Christian visual culture. At a macro-level we are dealing with the connection between the uterine taboo and the unveiling of Christ's face, that implies that Christianity-the Medusa as well as the vera icon, the true face of Christ, warding off evil-has never lost its fascination for the feminine as apotropaion (Gaignebet 1976).
But that also entails the working through of a hidden history in which menstruation, textiles, and the frontal face are knit together. Or to put it another way: the source of the iconic witness in some manner lies in female fluidity.

\section{Final Words}

The flow cured by Christ, the interruption in the stream, created the space for the image as living memorial (Figure 26). It again brings to mind the cut in the cloth, the sacred place encircled by the hem. Between the quarters of a lunar cycle, an image comes forth, potential, flowing, triumphantly displayed and borne on textile: the vera icon. How can we understand the origins of the image in the flow of blood otherwise than as a hystology? 
And should we in consequence not see this face that manifests in textile as the image of the figurating self: hysteria? Between the Haemorrhoissa and Veronica unfolds the mysterious ellipse that ties together fabric and making flesh.

"For it was you who formed my inward parts; you knit me together in my mother's womb [...] when I was being made in secret, intricately woven in the depths of the earth" (Psalm 139:13, 15). "The Word became flesh" (John 1:14).

The memory of the face of God could come about through the touching of a hem.

\section{Acknowledgments}

This article is part of the Research project-The Haemorrhaging Woman (Mark 5:24-34parr). An iconological research into the meaning of the bleeding woman in medieval art (fourth-fifteenth century). Also a contribution to the blood and touching taboo before the era of modernity-funded by the Research Fund of the Katholieke Universiteit Leuven (2008-12). I am grateful to my PhD students, Liesbet Kusters and Emma Sidgwick, and to Gerhard Wolf for the inspiring conversations.
Figure 26

Saint Veronica with the Sudarium, Master of Saint Veronica, c. 1420. London, National Gallery.

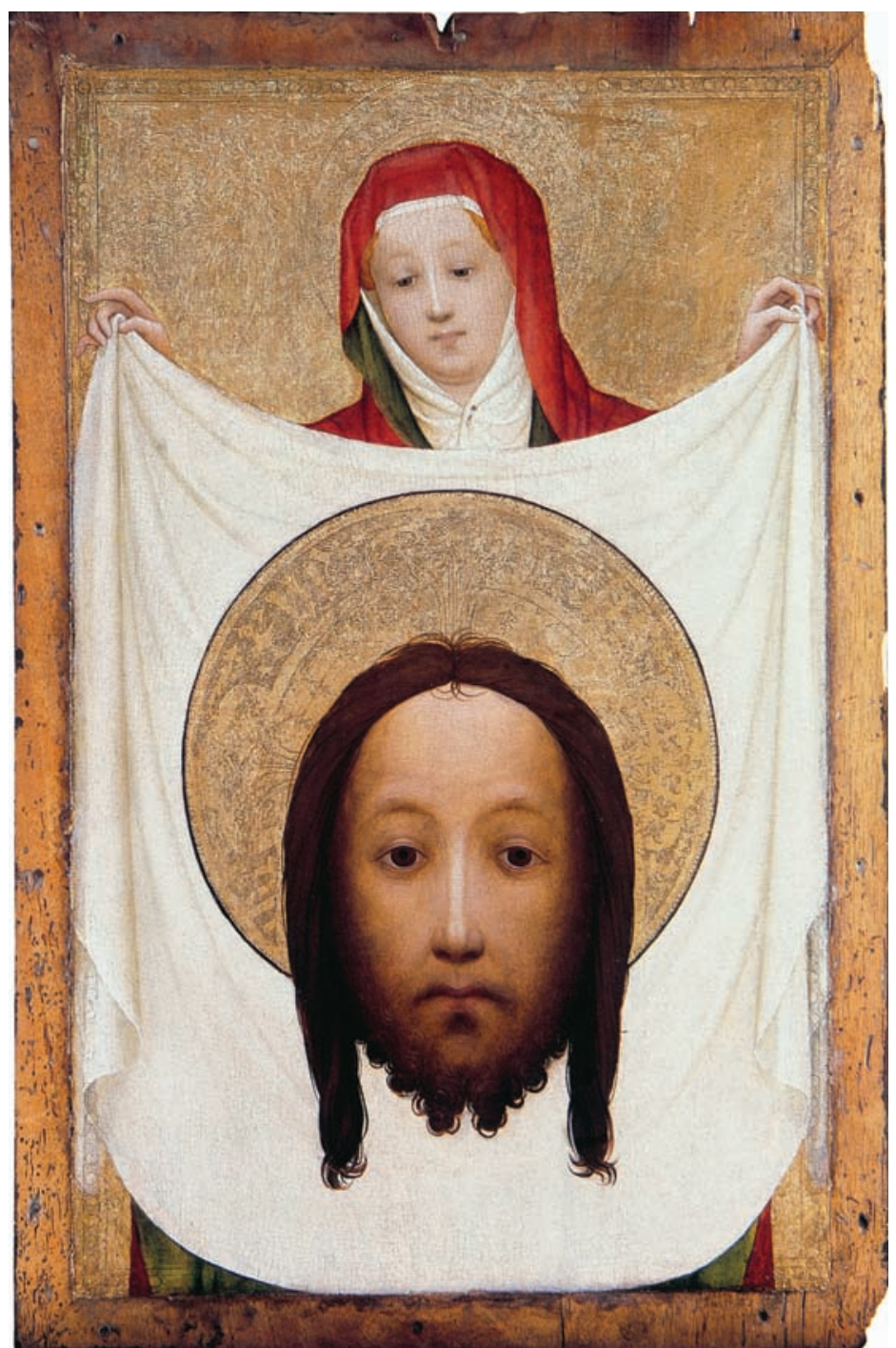




\section{Notes}

1. The Haemorrhoissa is treated in the following exegetical studies: Bovon (1991), D’Angelo (1999), Fonrobert (1997), Taylor Gench (2004), Haber (2003), Horsley (2001), Lemarquand (2004), Levine (1996), Marcus (2000), MelzerKeller (1997), Metternich (2000), Oppel (1995), Plaskow (1993), Schüssler Fiorenza (1994), Selvidge $(1984,1990)$, Söding (1985), Struthers Malbon (1992), Trummer (1991), Wilkinson (1998).

2. English quotation from the New Revised Standard Version (NRSV). The Vulgate reads:

et abiit cum illo et sequebatur eum turba multa et conprimebant illum et mulier quae erat in profluvio sanguinis annis duodecim et fuerat multa perpessa a conpluribus medicis et erogaverat omnia sua nec quicquam profecerat sed magis deterius habebat cum audisset de lesu venit in turba retro et tetigit vestimentum eius dicebat enim quia si vel vestimentum eius tetigero salva ero et confestim siccatus est fons sanguinis eius et sensit corpore quod sanata esset a plaga et statim lesus cognoscens in semet ipso virtutem quae exierat de eo conversus ad turbam aiebat quis tetigit vestimenta mea et dicebant ei discipuli sui vides turbam conprimentem te et dicis quis me tetigit et circumspiciebat videre eam quae hoc fecerat mulier autem timens et tremens sciens quod factum esset in se venit et procidit ante eum et dixit ei omnem veritatem ille autem dixit ei filia fides tua te salvam fecit vade in pace et esto sana a plaga tua.

3. Charlotte Fonrobert calls these tendencies the Jesuswas-a-feminist syndrome of the nineties. Fonrobert (1997: 124) refers to Selvidge (1984), "androcentric levitical writers," Barta (1991: 31), and Swidler (1971: 181).

4. See also Neusner (1973: 65), Parish Sanders (1998: 214-30, 1990: 258-71), Fredriksen (1995: 18-25, 42-47, 22-23), and Gilders (2004). According to D'Angelo (1999) there is no evidence that the touch of a menstruating woman's hand or brushing up against her in a crowd would have been considered polluting in the first century.

5. See Metternich (2000: 78-131) and Fonrobert (1997: 130): concerning zabâ (zvaha) and Leviticus: "The menstruant woman does transfer impurity by being touched (Lev. 15.19). However, Leviticus does not mention that she communicates impurity by touching. Milgrom comments that this "can only mean that in fact her hands do not transmit impurity [...]."” The Mishna is more severe: "He who touches a zav, or he whom a zav touches, transfers a status of impurity to food, drink and vessels that (can be purified by immersion)" (Fonrobert 1997: 131). But Leviticus does not say anything about the 
zabâ who touches another body. Only in the later Mishnah (sixth-seventh century) is the touching zabâ explicitly a transmitter of pollution and enjoined to live in isolation in the Beraita de Nidda (Biale 2007; Branham 1999; Buckley and Gottlieb 1988; Cohen 1991: 278; Fonrobert 2000; Lemay 1990; McCracken 2003; Walker Bynum 2007; Whitekettle 1996; Wood 1981).

6. Rhoads (1994) is seen by some authors as belonging to the same category, but in this case the Greek woman throws herself at Christ's feet to demand the healing of her daughter (Mark 7:24-30).

7. I refer to our research project Mary Magdalene and the Touching of Jesus. An Intra- and Interdisciplinary Investigation of the Interpretation of John 20, 17, funded by the Foundation for Scientific Research-Flanders, in the department of Art History and the faculty of Theology at the Catholic University of Leuven (2004-8). See the publications on touch, the senses, and Noli me tangere: Bieringer (2006, 2008a, b) and Baert (2008: 255-308, 2009b, c).

8. See also Grob (1967: 85-6) and De Bruyne (1943: 166-74).

9. See also Baert (2005).

10. This contrasts with Fonrobert (1997: 127, n. 17), who says that "[...] healing by touch is also a common element in Hellenistic healing stories."

11. So-called mana: a place in his theory of the relationships between representatives of the spiritual world and mankind (Hull 1974: 87, 108).

12. Examples taken from Lalleman (1997: 355-6).

13. Ginzburg (1998: 101): “Ces images, concentrées sur le punctum, sur l'instant décisif."

14. On these confusions, see Knipp (1998) and De Bruyne (1943: 166-74). Due to the sometimes ambiguous postures, some of the secondary literature confuses the Haemorrhoissa with the Noli me tangere motif, for instance in the catacomb murals, the Brescia Casket and the so-called Brivio Casket (this last in Noga-Banai 2008: 38-61, Fig. 3). In these three cases no disciples are shown to be present. Christ's gesture to the kneeling woman reaching towards his hem can be read either as a tactile gesture (compare the Chairete) or as a gesture of rejection-Noli me tangere. Christ's turned torso can also create confusion with the turning away of the Noli me tangere. We are convinced that an independent iconographic motif for the Noli me tangere arose only from Carolingian times onwards.

15. Trier, Stadtbibliothek, codex 24, fol. 91 (Schiel 1960; Ronig 2005: $78 \mathrm{ff}$.).

16. Healings and miracles of Christ, Court School of Charlemagne, early ninth century, ivory book cover, 211x124 cm, Oxford, Bodleian Library, Cod. Douce 176.

17. Christ and the Haemorrhoissa, detail from the so-called
"Tree Sarcophagus," Gaul, c. 350-60. Arles, Musée Lapidaire d'Art Chrétien.

18. Christ and the Haemorrhoissa, detail from the Sarcophagus of Adelphia, Rome, c. 340. Syracuse (Sicily), Museo Nazionale; Christ and the Haemorrhoissa, detail from a marble sarcophagus, Rome, 390, h.: $63.50 \mathrm{~cm}$, w.: 21.15 $\mathrm{cm}$. Leiden, Rijksmuseum van Oudheden, inv. no. $\mathrm{Pb} 35$.

19. Baltimore, Walters Art Gallery, Ms. Gr. 539 (Boeckler 1961: 9, Fig. 11).

20. So the story in Mark was to be interpreted also in a catechetical sense.

21. On this see Vandenbroeck (2009) and Warwick and Cavallaro (2001).

22. In the ancient Greek, dynamij means "potentiality" (Agamben 1999; Sidgwick 2009).

23. Translated from Connely (1929: 129, 254), Fonrobert (1997: 122), and Vööbus (1979).

24. Alphabetical Collection, A. 16, quoted in Viscuso (1991: 401).

25. The relationship between sacred space and the Eucharist goes beyond our present theme. See Walker Bynum (1992: 99, 2007).

26. Ambrosius, Expositio Evangelii secundam Lucam VI, 56-9, CCL, XIV, IV, 193-5; full text in Knipp (1998: 112-13).

27. Also shown by Kötzsche (1979: 440) and Nauerth (1983: 560, cat. no. 165). In Spier (1993: 44, n. 11) also refers to the Benaki Museum in Athens, which preserves a Middle Byzantine green chalcedony gem showing 
the Haemorrhoissa and the Crucifixion without inscription. Hematite is an iron ore that is not especially rare. This type of stone is characterized by a red core, which when worked (ground, polished) becomes black or silver.

28. Meier (1977: 394): "Hematites

(...) dicitur ab hema, quod est sanguis, et tithein, quod est sistere, quasi sistens sanguinem," following Petrus Berchorius (c. 1290-362), Reductorium morale XI, $\mathrm{p}$. 440a. In the same passage, Berchorius treats at some length of blood-flows due to "luxuria," "carnalis voluptas, mundana prosperitas, fluxusque cujuscunque iniquitatis," referring to the passage in Mark. "Figura de haemorrhoissa, quae ad tactum vestimenti Christi a fluxu sanguinis est sanata. Vestimentum Christi est abstinentia, quae re vera sanat $a b$ istis fluxibus animam peccatricem." The relationship between this disease and sin needs further investigation.

29. Spier (1993: 44): “The bronze token with the haemorhoïssa suggests that it had to help women in some way."

30. The throat is a "shaft," a gorgo (see below), a channel that in early-medieval medical and magical thought was considered a mirror of the uterus.

31. Photius, ninth century (Fabre 2007: 237, n. 19).

32. Philostorgios Historia Ecclesiasticae, VII, 3. See von Dobschütz (1899: 199-200, n. 1, and the original text on 257-9). See also Bidez (1913: 78-81).

33. See for these legends: Kusters, (2009).

34. See for this legend von Dobschütz (1899: 209-212; and for the original text pp. 157-203); Kuryluk (1991: 120).

35. "Veronica quae basilla [...] dicitur" (von Dobschütz 1899: 210, n. 1).

36. There is abundant literature on the Roman vera icon. I have used here: Dragon (1991), Kessler (1998), Koerner (1993: 80 passim), Morello and Wolf (2000), Wilson (1991: 112-13, Fig. 10, ill. 14, 21, and 111), and Wolf (1998, 2002: 50-2).

37. The daughter of the Canaanite woman (Mt 15:22) is also sometimes called Berenice. In the Pericopes of Henry III (1039-43), Bremen, Staatsbibliothek M. 21, fol. $28 \mathrm{v}$, the woman with an issue of blood is shown at the bottom, and in the upper register the episode of the Canaanite woman. In this episode, again, Christ is approached from behind.

38. Mentioned in Pradel (1907: 111).

39. Available at: http://www. indo-european.nl/. Another association is the intimacy of the edge of the bed, on the one side, and the shore of an island, on the other. There is perhaps, then, an association with the shore of the Sea of Galilee, which in the exegetical literature is also seen as a boundary and transit zone in Mark's redaction. See Struthers Malbon (1984). 
40. With thanks to Prof. Dr Silke Tammen and Prof. Dr Felix Thürlemann, who drew my attention to this research (Harlizius-Klück 2005).

41. There is no room here to develop further the association between opening, tear and the temporal epiphany in the iconography of the Annunciation. In his Le détail, Daniel Arasse fixes our attention upon the Annunciation by Filippo Lippi (c. 1450) in London's National Gallery, in which at the height of the navel a buttonhole was painted with no button. The tiny opening is barely visible to the naked eye. As Arasse studies several almostinvisible details in his book that-as the author developsshould be considered aspects of the enigmatic and intimate interconnections between the artist and his work of art, this particular lost button could enclose a symbolic meaning. The little tear, opening precisely on a single horizontal line with the dove, the power by which the Word was made flesh, is, for whoever sees it, a subtle suggestion of the navel as the paradox of a closed opening. It is virginal, as the iconography requires, but also sensual and erotic like the work of art. There are authors who would identify the model for this woman as Lucrezia Buti, a lady at the court of Prato, where the cintula, Our Lady's girdle, was preserved. The girdle with a single large knot around the navel symbolizes the binding and unbinding of fertility. We know that Filippo Lippi had an unbridled passion for this woman. A buried detail is the visible invisibility of Lippi's pictoriality itself. "Le désir du peintre dans la peinture même" (Arasse 1996: 340). On the navel, see Bronfen (1998: 26-30) and Baert (2009d).

42. On biblical hermeneutics and "lire au-delà du verset" (Lévinas), see Ouaknin (1994: $37,136,283)$.

43. Stated in yet a different sense: the hem as locus of this particular dynamic, as a liminal zone where transfer between the "l" and the "Other" are able to originate, is a locus of a certain transformational potentiality. This conception of the hem could be said to correlate to, or be a concrete and culturespecific expression of, what was psychoanalytically (or, even better: from the perspective of a correction on classical, orthodox Lacanian psychoanalysis) identified as "matrixial borderspace," a transsubjective psychic sphere, that can be grasped according to the model of the maternal womb (matrix) and its co-emergence-indifferentiation (fusion nor separation) of an I and an uncognized non-I, and their "borderlinking" as a nonfusional transmission, connectivity. In the matrixial perspective, frontiers become co-poietically transgressive and limits become thresholds. A matrixial borderspace is as such a mutating co- poietic net with a co-poietic transformational potentiality, where co-creativity ("metramorphosis") might occur. As such it equally entails a particular mode of meaning and knowledge production, and is able to describe certain aspects of human symbolic experience. See Ettinger (2006).

44. See for this Gnosticism: Kusters (2009). See also Pagels (1976) and Saelid Gilhus (1984).

45. See also King (1864: 27-31), Longueville Mansel (1875: 188), Maury (1850: 484-5, 1863: 341-2), and Réville (1863).

46. Irenaeus, Against the Heresies, 2.20.2; 1.3.3; 1.4.1 (Irenaeus of Lyons 1992), Origen (1953: 350), and Nilsson (1947: 169-72).

47. Irenaeus, Against the Heresies, 1.30.3-13 (Irenaeus of Lyons 1992: 95-102).

48. Irenaeus, Against the Heresies, 1.3.3 (Irenaeus of Lyons 1992: 28-9). The vision of the destroying Haemorrhoissa might derive from Zoroastrianism and the myth of the Great Whore who promised Ahriman, the Destructive Force of the universe, destruction and pollution in her menstruation. The sight of her blood encouraged Ahriman; he changed himself into a snake and cloaked the earth and the waters in darkness. The story is seen as reflecting a deep-rooted male fear of the feminine (Kuryluk 1991: 110; Zaehner 1975: 45-6). 
49. On menstruation in the premedicinal world, see Shail and Howie (2005).

50. Like hematite, the amethyst, with its purple-red color, alludes to the spectrum of blood; Baert (1997: 195-210).

51. See my article devoted to this issue: Baert (2000).

52. The mountain and the cave are parts of the matriarchal cosmogony (Meissner 1925: 11).

53. The so-called crux ansata is said to derive from the matrix.

\section{References}

Abel, Jenötöl (ed.). 1885. Orphica. Lipsiae: Freytag.

Agamben, Giorgio. 1999. "On Potentiality.” In Giorgio Agamben (ed.) Potentialities: Collected Essays in Philosophy, pp. 177-84. Stanford, CA: Stanford University Press.

Arasse, Daniel. 1996. Le détail: Pour une histoire rapprochée de la peinture. Paris: Flammarion.

Aretz, Erich, Embach, Michael, Persch, Martin and Roning, Franz (eds). 1996. Der Heilige Rock zu Trier: Studien zur Geschichte und Verehrung der Tunika Christi. Trier: Paulinus.

Asterius of Amasia. 1972. "Homily 1, PG 40, coll. 165-168.” In Cyril Mango (ed.) The Art of the Byzantine Empire 312-1453: Sources and Documents. Englewood Cliffs, N): Prentice Hall.

Baert, Barbara. 1997. "The Allegory with a Virgin: Contributions to the Solution of an Iconographical Enigma." In Hélène Verougstraete (ed.) Memling Studies: Proceedings of the International Colloquium (Bruges, November 10-12, 1994). Leuven: Peeters, pp. 195-210.

Baert, Barbara. 2000. "The Gendered Visage: Facets of the Vera Icon." Antwerp Royal Museum Annual: 10-43.

Baert, Barbara. 2002. "La Piscine Probatique à Jérusalem. L'eau médicinale au Moyen Age." In Bert Cardon and Jan Van der Stock (eds) "Als Ich Can": Liber Amicorum in Memory of Professor Dr. Maurits Smeyers. Leuven: Peeters, pp. 91-129.

Baert, Barbara. 2004. "The Wood, The Water, and the Foot, or how the Queen of Sheba Met up with the True Cross: With Emphasis on the Northern European Iconography." Mitteilungen für Anthropologie und Religiongeschichte (MARG), 16: 217-78.

Baert, Barbara. 2005. "The Pool of Bethsaïda: The Cultural History of a Holy Place in Jerusalem." Viator: Medieval and Renaissance Studies 36: 1-22.

Baert, Barbara. 2006. "Wasserkrug und Kamm. Die Darstellung der Verena von Zurzach, ein Beispiel für neue Tendenzen in der ikonologischen Methodik." Österreichische Zeitschrift für Volkskunde 60(109): 35-62.

Baert, Barbara. 2007. "The Healing of the Blind Man at Siloam, Jerusalem: A Contribution to the Relationship between Holy Places and the Visual Arts in the Middle Ages." Arte Cristiana 838: 49-60; 839: 121-30.

Baert, Barbara. 2008. "The Twilight Zone of the Noli me tangere: Contributions to the History of 
the Motif in Western Europe (ca. 400-ca. 1000)." Louvain Studies 32: 255-308.

Baert, Barbara. 2009a. "'Who Touched Me and My Clothes?' The Healing of the Woman with the Haemorrhage (Mark 5:24b-34parr) in Early Medieval Visual Culture." Antwerp Royal Museum Annual (in press).

Baert, Barbara. 2009b. "In Touch with Jerusalem: Noli me tangere, Narrative Space and Iconic Space." Antwerp Royal Museum Annual (in press).

Baert, Barbara. 2009c. "The Pact between Space and Gaze: The Narrative and the Iconic in Noli me tangere." In Ralph Dekoninck and Agnes Guiderdoni (eds) To Tell, to Think and to Experience Images from Theology to Rhetoric and Aesthetics in the Early Modern Period, Leuven (in press).

Baert, Barbara. 2009d. Navel: On the Origin of Things. Leuven: Baert.

Barasch, Moshe. 1987. Giotto and the Language of Gesture. Cambridge: Cambridge University Press.

Barb, Alfons A. 1948. "St. Zacharias the Prophet and Martyr. A Study in Charms and Incantations." Journal of the Warburg and Courtauld Institutes 11: 35-67.

Barb, Alfons A. 1953. "Diva Matrix." Journal of the Warburg and Courtauld Institutes 16: 193-238.

Barta, Karen A. 1991. "Paying the Price of Paternalism." In MarieEloise Rosenblatt (ed.) Where Can We Find Her? New York: Paulist.
Beyer, Rolf. 1987. Die Königin von Saba. Engel und Dämon. Der Mythos einer Frau. Bergisch Gladbach: Lübbe.

Biale, David. 2007. Blood and Belief: The Circulation of a Symbol between Jews and Christians. Berkeley, CA: University of California Press.

Bidez, Joseph. 1913. Philostorgius Kirchengeschichte mit dem Leben des Lucian von Antiochiën und den Fragmenten eines Arianischen Historiographen. Leipzig: Hinrichs'sche Buchhandlung.

Bieringer, Reimund. 2005. “'Nader Mij niet': De betekenis van mê mou haptou in Johannes 20:17." HTS Teologiese Studies/Theological Studies 61: 19-43.

Bieringer, Reimund. 2006. "Noli me tangere and the New Testament." In Barbara Baert, Reimund Bieringer, Karlijn Demasure and Sabine Van Den Eynde (eds) "Noli me tangere". Mary Magdalene: One Person, Many Images (Documenta libraria, 32). Leuven: Peeters, pp. 16-28.

Bieringer, Reimund. 2008a. “'I am ascending to my Father and your Father, to my God and your God' (John 20:17): Resurrection and Ascension in the Gospel of John." In Craig R. Koester and Reimund Bieringer (eds) The Resurrection of Jesus in the Gospel of John (WUNT, 222). Tübingen: Mohr, pp. 209-35.

Bieringer, Reimund. 2008b.

“'They have taken away my Lord':

Text-Immanent Repetitions and Variations in John 20:1-18." In Gilbert Van Belle (ed.) Repetitions and Variations in the Fourth Gospel: Style, Text, Interpretation. Leuven: Peeters, pp. 609-30.
Boeckler, Albert. 1961. Ikonographische studien zu den Wunderscenen der Ottonischen Malerei des Reichenau. Munich: Bayerische Akademie der Wissenschaften.

Bovon, François. 1991. L'évangile selon saint Luc (Commentaire du Nouveau Testament, 3a). Geneva: Labor et Fides, pp. 431-40.

Branham, Joan R. 1999. "Frauen und blutige Räume. Menstruation und Eucharistie in Spätantike und Mittelalter." Vorträge WarburgHaus 3: 129-61.

Bromley, Donald H. 2005. "The Healing of the Hemorrhaging Woman: Miracle or Magic." Journal of Biblical Studies 5(1): 1-20.

Bronfen, Elisabeth. 1998. Das verknotete Subjekt: Hysterie in der Moderne. Berlin: Volk und Welt.

Buckley, Thomas and Gottlieb, Alma. 1988. Blood Magic: The Anthropology of Menstruation. Berkeley, CA: University of California Press.

Bugge, Ragne. 1975. “"Effigiem Christi, qui transis, semper honora.' Verses Condemning the Cult of Sacred Images in Art and Literature." Acta ad archaeologiam et artium historiam pertinentia VI: 127-39.

Cambrensis, Giraldus. 1873. Speculum Ecclesiae, lib. IV, 6: Rerum Britannicarum Medii Aevi Scriptores, Vol. 21, 4, $274 \mathrm{ff}$. London: Longman.

Camporesi, Piero. 1995. Juice of Life: The Symbolic and Magic Significance of Blood. New York: Continuum.

Clark Kee, Howard. 1983. Miracle in the Early Christian World: A Study 
in Sociohistorical Method. New Haven, CT: Yale University Press, pp. 162-3.

Clark Kee, Howard. 1984. Medicine, Miracle and Magic in New Testament Times. Cambridge: Cambridge University Press.

Cohen, Shaye. 1991. "Menstruants and the Sacred in Judaism and Christianity." In Sarah B. Pomeroy (ed.) Women's History and Ancient History. Chapel Hill, NC: The University of North Carolina Press, pp. pp. 273-300.

Connely, Richard H. 1929. Didascalia Apostolorum. Oxford: Clarendon Press.

Cotter, Wendy. 1999. Miracles in Greco-Roman Antiquity: $A$ Sourcebook. London: Routledge.

Culiano, Ioan P. 1987. “Gnosticism from the Middle Ages to the Present." In Mircea Eliade (ed.) The Encyclopedia of Religion. New York and London: Macmillan, pp. 574-8.

Cummings, John T. 1980. "The Tassel of His Cloak: Mark, Luke, Matthew and Zechariah." In Elizabeth A. Livingstone (ed.) Papers on the Gospels. Sixth International Congress on Biblical Studies, Oxford, April 3-7, 1978. (Studia Biblica, 2). Sheffield: Sheffield Academic Press, pp. 47-61.

D’Angelo, Mary Rose. 1999 “Gender and Power in the Gospel of Mark: The Daughter of Jairus and the Woman with the Flow of Blood." In John C. Cavadini (ed.) Miracles in Jewish and Christian Antiquity: Imagining Truth (Notre Dame Studies in Theology, 3). Notre Dame: University of Notre Dame Press, pp. 83-109.
De Bruyne, Lucien. 1943. L'imposition des mains dans l'art Chrétien ancien. Vatican City: Pontificio istituto di archeologia cristiana.

Deckers, Johannes G., Hans R. Seeliger and Gabriele L. Mietke. 1987. "Die Katakombe 'Santi Marcellino e Pietro.'” Repertorium der Malereien. Vatican City and Münster: Pontificio istituto di archeologia cristiana, pp. 223-343.

Demyttenaere, Albert. 1990. "The Cloth and the Stain." In Werner Affeldt (ed.) Fraue in Spätantike und Frühmittelalter: Lebensbedingungen, Lebensnormen, Lebensformen. Sigmaringen: Thorbecke, pp. 141-66.

Dr Aigremont (pseudonym of Siegmar Schultze-Gallera). 1909. Fusz- und Schuh-Symbolik und Erotik. Folkloristische und sexualwissenschaftliche Untersuchungen. Darmstadt: Bläschke.

Dragon, Gilbert. 1991. "Holy Images and Likeness." Dumbarton Oaks Papers 45: 23-33.

Ebermann, Oskar. 1903. Blut- und Wundsegen in ihrer Entwicklung dargestellt. (Palaestra, 24). Berlin: publisher unknown.

Edersheim, Alfred. 1951. The Temple: Its Ministry and Services as They Were at the Time of Jesus Christ. Grand Rapids, MI: Eerdmans.

Eisler, Robert. 1930. "La prétendue statue de Jésus et de l'Hémorroïsse a Panéas." Revue archéologique 31: 18-27. 
Ettinger, Bracha L. 2006. The Matrixial Borderspace. Minneapolis, MN: The University of Minnesota Press.

Eusebius of Caesarea. 1955. Histoire écclesiastique. Trans. Gustave Bardy. Paris: Cerf.

Fabre, Pierre-Antoine. 2007. “L'image possible. Réflexions sur le défaut d'illustration dans les écrits prescriptifs et défensifs sur l'image au XVle siècle." In Ralph Dekonick and Agnes GuiderdoniBruslé (eds) Emblemata sacra. Rhétorique et herméneutique du discours sacré en images. The Rhetoric and Hermeneutics of Illustrated Sacred Discourse (Imago Figurata Studies, 7). Turnhout: Brepols, pp. 229-51. Fitzmyer, Joseph. 1985. The Gospel According to Mark. New York: Doubleday.

Fonrobert, Charlotte. 1997. "The Woman with a Blood-Flow (Mark 5:24-34) Revisited: Menstrual Laws and Jewish Culture in Christian Feminist Hermeneutics." In Craig A. Evans and James A. Sanders (eds), Early Christian Interpretation of the Scriptures of Israel: Investigations and Proposals. (JSNTS, 148-Studies in Scripture in Early Judaism and Christianity, 5). Sheffield: Sheffield Academic Press, pp. 121-40.

Fonrobert, Charlotte. 2000. Menstrual Purity: Rabbinic and Christian Reconstructions of Biblical Gender. Stanford, CA: Stanford University Press.

Frazer, Margaret and Karl Weitzman (eds). 1977. The Age of Spirituality. Princeton, NJ: Princeton University Press.
Fredriksen, Paula. 1995. "Did Jesus Oppose the Purity Laws?" Bible Review 11: 18-25, 42-7.

Gaignebet, Claude. 1976.

"Véronique ou l'Image-Vraie." Anagrom 7: 45-70.

Gandelman, Claude. 1986. Le regard dans le texte. Image et écriture du Quattrocento au XXe siècle. Paris: Méridiens Klincksieck, pp. 107-12.

Gilders, William K. 2004. Blood Ritual in the Hebrew Bible: Meaning and Power. Baltimore, MD: Johns Hopkins University Press.

Ginzburg, Carlo. 1998. A distance. Neuf essays sur le point de vue en histoire. Paris: Gallimard.

Grob, Rudolf. 1967. “Art. Berühren.” In Lothar Coenen (ed.) Theologisches Begriffslexikon zum Neuen Testament. Wuppertal: Theologischer Verlag, pp. 85-6.

Haber, Susan. 2003. “A Woman's Touch: Feminist Encounters with the Hemorrhaging Woman in Mark 5.24-34." Journal for the Study of the New Testament 26(2):

171-92.

Harlizius-Klück, Ellen. 2005. Saum und Zeit: Ein Wörter-und Sachen-Buch in 496 lexikalischen Abschnitte angezettelt. Berlin: Edition Ebersbach.

Haulotte, Edgar. 1966. Symbolique du vêtement selon la bible. Paris: Aubier.

Horsley, Richard A. 2001. Hearing the Whole Story: The Politics of Plot in Mark's Gospel. Louisville, KY: Westminster John Knox Press.

Hull, John M. 1974. Hellenistic Magic and the Synoptic Tradition
(Studies in Biblical Theology. Second Series, 28). Napperville, IL: Allenson.

Irenaeus of Lyons. 1992. Against the Heresies. Trans. Dominic J. Unger (Ancient Christian Writers: The Works of the Fathers in Translation, no. 55). New York: Paulist.

Kessler, Herbert L. 1998.

"Configuring the Invisible by Copying the Holy Face." In The Holy Face and the Paradox of Representation (Proceedings). Bologna: Nuova Alfa Editoriale, pp. 130-51.

King, Charles W. 1864. The Gnostics and their Remains. London: Bell and Daldy.

Knipp, David. 1998. Christus medicus in der früchristlichen Sarkophagskulptur. Ikonographische Studien der Sepulkralkunst des späten vierten Jahrhunderts. Leiden: Brill.

Koerner, Joseph L. 1993. The Moment of Self-Portraiture in German Renaissance Art. Chicago, IL, and London: University of Chicago Press.

Kötzsche, Lieselotte. 1979. In Karl Weitzmann (ed.) Age of Spirituality. Late Antique and Early Christian Art, Third to Seventh Century. Princeton, NJ: Princeton University Press.

Kuryluk, Ewa. 1991. Veronica and Her Cloth: History, Symbolism, and Structure of a "True" Image. Oxford: Blackwell.

Kusters, Liesbet. 2009. "Who is She? The Identity of the Hemorrhaging Woman and Her Wirkungsgeschichte." Antwerp Royal Museum Annual: 99-133 
Lalleman, Pieter J. 1997. "Healing by a Mere Touch as a Christian Concept." Tyndale Bulletin 48(2): 335-61.

Le Quéré, François. 1997 La sainte tunique d'Argenteuil: Histoire et examen de l'authentique tunique sans couture de Jésus-Christ. Paris: de Guibert.

Lemarquand, Grant. 2004. An Issue of Relevance: A Comparative Study of the Story of the Bleeding Woman (Mk 5:25-34; Mt 9:20-22; Lk 8:43-48) in North Atlantic and African Contexts. New York: Peter Lang.

Lemay, Helen. 1990. "Women and the Literature of Obstetrics and Gynecology." In Joel T. Rosenthal (ed.) Medieval Women and Medieval History. Athens, GA: University of Georgia Press, pp. 189-209.

Levine, Amy-Jill. 1996. "Discharging Responsibility: Matthean Jesus, Biblical Law and Hemorrhaging Woman." In David R. Bauer and Mark A. Powell (eds) Treasure New and Old: Recent Contributions to Matthean Studies. Atlanta, GA: Scholars Press, pp. 379-97.

Leyerle, Blake. 2001. "Blood is Seed." Journal of Religion 81(1): 26-48.

Longueville Mansel, Henry. 1875. The Gnostic Heresies of the First and Second Centuries. London: John Murray.

Lurker, Manfred. 1991. "Art. Gefäss.” In Wörterbuch der Symbolik. Stuttgart: Kröner, pp. 232-3.

Mancinelli, Fabrizio. 1987. De Romeinse catacomben en de wortels van het Christendom. Florence: Scala.

Marcus, Joel. 2000. Mark 1-8: A New Translation with Introduction and Commentary. New York: Doubleday.

Marshall, Christopher D. 1989. Faith as a Theme in Mark's Narrative (Society for New Testament Studies. Monograph Series, 64). Cambridge: Cambridge University Press, pp. 106-8.

Mathews, Thomas F. 1993. The Clash of Gods: A Reinterpretation of Early Christian Art. Princeton, N): Princeton University Press.

Maury, Alfred. 1850. "Lettre à M. Raoul Rochette sur l'étymologie du nom de Véronique." Revue Archéologique 7: 484-95.

Maury, Alfred. 1863. Croyances et légendes de l'antiquité. Paris: Cerf.

May, Eric E. 1952. “'For Power Went Forth from Him...' (Luke 6:19).” Catholic Biblical Quarterly 14(2): 93-103.

McCracken, Peggy. 2003. The Curse of Eve, The Wound of the Hero: Blood, Gender and Medieval Literature (The Middle Ages Series). Philadelphia, PA: University of Pennsylvania Press.

Meier, Christel. 1977. Gemma Spiritualis. Methode und Gebrauch der Edelsteinallegorese vom frühen Christentum bis ins 18. Jahrhundert. Munich: Wilhelm Fink Verlag.

Meissner, Bruno. 1925. Babylonien und Assyrien, Vol. 1. Heidelberg: Winter.

Melzer-Keller, Helga. 1997. Jesus und die Frauen. Eine 
Verhältnisbestimmung nach den synoptischen Überlieferungen. (Herders biblische Studien, 14). Freiburg: Herder.

Metternich, Ulrike. 2000. "Sie sagte ihm die ganze Wahrheit": Die Erzählung von der "Blutflüssigen" feministisch gedeuted. Mainz: Matthias Grünewald Verlag.

Morello, Giovanni and Gerhard Wolf. 2000. Il volto di Cristo (exhibition catalog), Rome, Palazzo delle Esposizioni. Milan: Electa.

Murray, Margaret A. 1911. "Note on the SA Sign." Man 11(73): 113-77.

Nancy, Jean-Luc. 2000. Corpus. Paris: Editions Métailié.

Nancy, Jean-Luc. 2008. Corpus. Trans. Richard A. Rand. New York: Fordham University Press.

Nauerth, Claudia. 1983. "Heilungswunder in der frühchristlichen Kunst.” In Herbert Beck and Peter C. Bol (eds) Spätantike und frühes Christentum. Frankfurt am Main: Liebieghaus Museum alter Plastik, pp. 339-46. Neumann, Erich. 1956. Die Grosse Mutter. Zurich: Rhein Verlag.

Neusner, Jacob. 1973. The Idea of Purity in Ancient Judaism. Leiden: Brill.

Nilsson, Martin P. 1947. "SophiaPrunikos.” Eranos. Acta Philologica Suecana 45(1-2): 169-72.

Oppel, Dagmar. 1995. Heilsam erzählen-erzählend heilen. Die Heilung der Blutflüssigen und die Erweckung der Jairustochter in Mk 5,21-43 als Beispiel markinischer Erzählfertigkeit (Bonner biblische Beiträge, 102). Weinheim: Beltz.
Origen. 1953. Contra Celsum, VI, 35. Trans. Henry Chadwick. Cambridge: Cambridge University Press.

Ouaknin, Marc-Alain. 1994. Lire aux éclats: Éloge de la caresse. Paris: Seuil.

Noga-Banai, Galit. 2008. The Trophies of the Martyrs: An Art Historical Study of Early Christian Silver Reliquaries. Oxford: Oxford University Press.

Pagels, Elaine H. 1976. "What Became of God the Mother? Conflicting Images of God in Early Christianity." Signs 2(2): 293-303.

Paracelsus. 1922-33. "De matrice." In Karl Sudhoff (ed.) Sämtliche Werke, Vol. 9. Munich: Oldenbourg.

Parish Sanders, Ed. 1990. Jewish Law from Jesus to the Mishnah. London: SCM.

Parish Sanders, Ed. 1998. Judaism. Practice and Belief. 63BCE-66CE. London: SCM.

Pettazzoni, Raffaele. 1921. "Le origini della testa di Medusa." Bolletino d'arte 1: 491-509.

Plaskow, Judith. 1993.

"Antijudaism in Feminist Christian Interpretation." In Elisabeth Schüssler Fiorenza (ed.) Searching the Scriptures: A Feminist Introduction. New York: Crossroad, pp. 117-29.

Pointon, Marcia. 1986. "Interior Portraits: Women, Physiology and the Male Artist." Feminist Review 22: 5-22.

Pradel, Fritz. 1907. Griechische und Süditalische Gebete, Beschwörungen und Rezepte des Mittelalters. Giessen: Töpelmann.
Réville, A. 1863. "La Véronique, une sainte Gnostique.” Le Lien 28.

Rhoads, David. 1994. “Jesus and the Syrophoenician Woman: A Narrative-Critical Study." Journal of the American Academy of Religion 62(2): 343-75.

Robertson, Archibald T. and Perschbacher, Wesley J.. 2004. Word Pictures of the New Testament, Vol. 1. Matthew and Mark. Grand Rapids, MI: Kregel.

Ronig, Franz J. 2005.

"Erläuterungen zu den Miniaturen des Egbert Codex." In Sif D. Dornheim, Doris Oltrogge, Robert Fuchs, Franz J. Ronig and Günther Franz (eds) Der Egbert Codex. Das Leben Jesu. Ein Höhepunkt der Buchmalerei vor 1000 Jahren. Stuttgart: Theiss.

Rubin, Nissan and Kosman, Admiel. 1997. "The Clothing of the Primordial Adam as a Symbol of Apocalyptic Time in the Midrashic Sources." Harvard Theological Review 90(2): 155-74.

Ryken, Leland. 1998. “Art. Garments." In Leland Ryken and James C. Wilhoit (eds) Dictionary of Biblical Imagery. Downers Grove, IL: InterVarsity Press, pp. 317-20.

Saelid Gilhus, Ingvild. 1984. "Gnosticism: A Study in Liminal Symbolism.” Numen 1(31): 106-28.

Schiel, Hubert. 1960. Codex Egberti der Stadtbibliothek Trier. Basel: Alkuin.

Schiller, Gertrud. 1971. Iconography of Christian Art, Vol. 1. Christ's Incarnation, Childhood, Baptism, Temptation, Transfiguration, Works and Miracles. Trans. Janet Seligman. London: Humphries. 
Schüssler Fiorenza, Elisabeth. 1994. In Memory of Her: A Feminist Theological Reconstruction of Christian Origins. New York: Crossroad.

Selvidge, Marla J. 1984. "Mark 5:25-34 and Leviticus: A Reaction to Restrictive Purity Regulations." Journal of Biblical Literature 104(4): 619-23.

Selvidge, Marla J. 1990. Woman, Cult, and Miracle Recital: $A$ Redactional Critical Investigation on Mark 5:24-34, London and Toronto: Bucknell University Press.

Shail, Andrew and Howie, Gillian (eds). 2005. Menstruation: A Cultural History. New York: Palgrave Macmillan.

Sidgwick, Emma. 2009. Tactiliteit en potentialiteit in het motief van de Haemorrhoissa (Mc 5:2434parr). "Cultureel-antropologische verkenningen.” Antwerp Royal Museum Annual: 135-61.

Söding, Thomas. 1985. Glaube bei Markus. Glaube an das Evangelium, Gebetsglaube und Wunderglaube im Kontext der markinischen Basileiatheologie und Christologie (Stuttgarter Biblische Beiträge, 12). Stuttgart: Katholisches Bibelwerk, pp. 414-21.

Spier, Jeffrey. 1993. "Medieval Byzantine Magical Amulets and Their Tradition." Journal of the Warburg and Courtauld Institutes 56: 25-62.

Struthers Malbon, Elizabeth. 1984. "The Jesus of Mark and the Sea of Galilee." Journal of Biblical Literature 103(3): 363-77.

Struthers Malbon, Elizabeth. 1992. "Narrative Criticism: How Does the
Story Mean?" In Janice C. Anderson and Stephen D. Moore (eds) Mark and Method: New Approaches in Biblical Studies. Minneapolis, MN: Fortress Press, pp. 23-47.

Swidler, Leonard. 1971. "Jesus was a Feminist." Catholic World 212: 177-83.

Taylor Gench, Frances. 2004. Back to the Well: Women's Encounters with Jesus in the Gospels. Louisville, $\mathrm{KY}$, and London: Westminster John Knox Press. Teteriatnikov, Natalia. 1995. "The Place of the Nun Melania (the Lady of the Mongols) in the Deesis Inner Narthex of Chora, Constantinoplei." Cahiers Archéologiques 43: 163-80.

Theissen, Gerd. 1983. The Miracle Stories of the Early Christian Tradition. Philadelphia, PA: Fortress Press.

Trummer, Peter. 1991. Die Blutende Frau. Wunderheilung im Neuen Testament. Freiburg and Vienna: Herder.

Twelftree, Graham H. 1999. Jesus the Miracle Worker: A Historical and Theological Study. Downers Grove, IL: InterVarsity Press.

Underwood, Paul. 1966. The Kariye Djami. Vol. 1: Historical Introduction and Description of the Mosaics and Frescoes. New York: Pantheon Books.

van der Loos, Hendrik. 1965. The Miracles of Jesus. (Novum Testamentum Supplementum, 9). Leiden: Brill.

van Loo, Sofie (ed.). 2007. Gorge(l): Oppression and Relief in Art. Antwerp: Royal Museum of Fine Art. 
Vandenbroeck, Paul. 2000. Azetta. Berbervrouwen en hun kunst, (exhibition catalog), Brussels, Palais des Beaux-Arts. Ghent: Ludion.

Vandenbroeck, Paul. 2009. "The Energetics of an Unknowable Body." In Paul Vandenbroeck and Gerard Rooiakkers (ed.) Backlit Heaven: Power and Devotion. Mechelen: LAMOT, pp. 174-205.

Veith, Ilza. 1965. Hysteria: The History of a Disease. Chicago, IL: University of Chicago Press.

Verhoeven, Cornelius W. M. 1956. "Symboliek van de voet." Doctoral dissertation, Assen.

Viscuso, Patrick. 1991. "Purity and Sexual Defilement in Late Byzantine Theology." Orientalia Christiana Periodica 57: 399-408.

von Dobschütz, Ernst. 1899. Christusbilder. Untersuchungen zur christlichen Legenden. Leipzig: Hinrichs.

Vööbus, Arthur. 1979. The Didascalia Apostolorum in Syriac (CSCO, 401-2, 407-8). Leuven: Peeters.
Waagenvoort, Hans. 1957. “Contactus." Revue de Archéologie Chrétienne 3: 404-42.

Walker Bynum, Caroline. 1992. Fragmentation and Redemption: Essays on Gender and the Human Body in Medieval Religion. New York: Zone Books.

Walker Bynum, Caroline. 2007. Wonderful Blood: Theology and Practice in Late Medieval Northern Germany and Beyond. Philadelphia, PA: University of Pennsylvania Press.

Warwick, Alexandra and Cavallaro, Dani. 2001. Fashioning the Frame: Boundaries, Dress and the Body. Oxford: Berg Publishers, pp. 72-88.

Watson, Carolyn J. 1981. "The Program of the Brescia Casket." Gesta 20(2): 283-98.

Whitekettle, Richard W. 1996. "Levitical Thought and the Female Reproductive Cycle: Wombs, Wellsprings, and the Primeval World." Vetus Testamentum 46(3): 376-91.

Wilkinson, John. 1998. The Bible and Healing: A Medical and Theological Commentary. Grand Rapids, MI: Eerdmans.
Wilson, Ian. 1991. Holy Faces, Secret Places: The Quest for Jesus' True Likeness. London: Doubleday.

Wolf, Gerhard. 1998. "From Mandylion to Veronica: Picturing the 'Disembodied' Face and Disseminating the True Image of Christ in the Latin West." In The Holy Face and the Paradox of Representation (Proceedings). Bologna: Bologna: Nuova Alfa Editoriale, pp. 153-79.

Wolf, Gerhard. 2002. Schleier und Spiegel. Traditionen des Christusbildes und die Bildkonzepte der Renaissance. Munich: Wilhelm Fink.

Wolf, Gerhard, Bozzo, Colette D. and Calderoni Masetto, Anna R. 2004. Mandylion: Intorno al Sacro Volto, da Bisanzio a Genova. Milan: Skira Editore.

Wood, Charles T. 1981. "The Doctor's Dilemma: Sin, Salvation, and the Menstrual Cycle in Medieval Thought." Speculum 56(4): 710-27.

Zaehner, Robert C. 1975. The Teachings of the Magi. London: Sheldon Press. 